\title{
Influence of Culture Media on Biofilm Formation by Candida Species and Response of Sessile Cells to Antifungals and Oxidative Stress
}

\author{
Isela Serrano-Fujarte, ${ }^{1}$ Everardo López-Romero, ${ }^{1}$ Georgina Elena Reyna-López, ${ }^{1}$ \\ Ma. Alejandrina Martínez-Gámez, ${ }^{2}$ Arturo Vega-González, ${ }^{3}$ and Mayra Cuéllar-Cruz ${ }^{1}$ \\ ${ }^{1}$ Departamento de Biología, División de Ciencias Naturales y Exactas, Universidad de Guanajuato, Campus Guanajuato, \\ Noria Alta S/N, 36050 Guanajuato, GTO, Mexico \\ ${ }^{2}$ Centro de Investigaciones en Optica AC, Loma del Bosque 115, Col. Lomas del Campestre, 37150 León, GTO, Mexico \\ ${ }^{3}$ Departamento de Ingeniería Química, Electrónica y Biomédica, División de Ciencias e Ingenierías, \\ Universidad de Guanajuato, Campus León, 37150 León, GTO, Mexico \\ Correspondence should be addressed to Mayra Cuéllar-Cruz; mcuellar@ugto.mx
}

Received 7 September 2014; Revised 31 October 2014; Accepted 3 November 2014

Academic Editor: Mahmoud Rouabhia

Copyright (c) 2015 Isela Serrano-Fujarte et al. This is an open access article distributed under the Creative Commons Attribution License, which permits unrestricted use, distribution, and reproduction in any medium, provided the original work is properly cited.

\begin{abstract}
The aims of the study were to evaluate the influence of culture media on biofilm formation by C. albicans, C. glabrata, C. krusei, and C. parapsilosis and to investigate the responses of sessile cells to antifungals and reactive oxygen species (ROS) as compared to planktonic cells. For biofilm formation, the Candida species were grown at different periods of time in YP or YNB media supplemented or not with 0.2 or $2 \%$ glucose. Sessile and planktonic cells were exposed to increasing concentrations of antifungals, $\mathrm{H}_{2} \mathrm{O}_{2}$, menadione or silver nanoparticles (AgNPs). Biofilms were observed by scanning electron microscopy (SEM) and quantified by the XTT assay. C. albicans formed biofilms preferentially in YPD containing $2 \%$ glucose (YPD/2\%), C. glabrata in glucosefree YNB or supplemented with $0.2 \%$ glucose $(\mathrm{YNB} / 0.2 \%)$, while C. krusei and C. parapsilosis preferred $\mathrm{YP}, \mathrm{YPD} / 0.2 \%$, and $\mathrm{YPD} / 2 \%$. Interestingly, only C. albicans produced an exopolymeric matrix. This is the first report dealing with the in vitro effect of the culture medium and glucose on the formation of biofilms in four Candida species as well as the resistance of sessile cells to antifungals, AgNPs, and ROS. Our results suggest that candidiasis in vivo is a multifactorial and complex process where the nutritional conditions, the human immune system, and the adaptability of the pathogen should be considered altogether to provide an effective treatment of the patient.
\end{abstract}

Dedicated to the late Julio César Cuéllar-Cruz who will always be remembered as the beloved brother whom inspired me all the time to pursuit my goals and who was also an example of perseverance to all our family members

\section{Introduction}

Candida species are part of the normal flora of healthy individuals $[1,2]$ and are considered opportunistic pathogens as they colonize different tissues and cause systemic mycosis when the immune system of the host is depressed [3]. The commensal-pathogen shift requires an effective adaptation of Candida species to a particular environment in the human host in order to colonize it $[4,5]$. It has been observed that the carbon source, which varies in the different tissues, is critical for colonization. For instance, the skin surface and mucosa contain low amounts of sugars, whereas the bloodstream may contain high levels of glucose [5-8]. This is important as $C$. albicans requires glucose or fructose to invade the genitourinary tract, whereas C. glabrata requires lactate to proliferate in the intestinal tract [8]. In addition to nutritional adaptation, Candida species express virulence factors that allow them to infect the host such as adhesins, 
yeast to hyphae switching, hydrolases, thigmotropism, and biofilm formation and to response to oxidative stress (OSR) [9-14]. Among these, biofilm formation is of special interest as this ability has been associated with high rates of morbility and mortality in hospitalized patients $[2,15,16]$. C. albicans is the most frequently isolated pathogen from patients with disseminated candidiasis [17-19]. However, due to the indiscriminate use of wide-spectrum antibiotics [20-25] and medical implants, other non-Candida albicans Candida (NCAC) species, formerly considered as nonpathogenic, have emerged as frequent agents of human mycoses [13, 14]. Recurrent mycoses associated with NCAC are difficult to treat since some of these pathogens such as C. glabrata, C. krusei, and C. tropicalis are resistant to azole-based drugs [26-28]. On the contrary, C. albicans and C. parapsilosis are sensitive to fluconazole $[29,30]$. Though the mechanisms of resistance of Candida species have not been completely elucidated, an attractive hypothesis is that biofilm formation on the surface of medical implants may confer protection to the pathogen [2]. This is due to the fact that cells in a biofilm community are irreversibly bound to a surface (sessile cells) and frequently embedded in an exopolymeric matrix, exhibiting distinct properties as compared to planktonic cells [31-33]. Sessile cells are highly resistant to antifungals and to the host mechanisms of defense [2, 31, 34-40], which makes biofilms a permanent source of infection as they are not only resistant to antifungals but also to the reactive oxygen and nitrogen species (ROS, RNS) produced during respiratory burst in human phagocytes. In line with this notion, it has been demonstrated that enzymes involved in $\mathrm{H}_{2} \mathrm{O}_{2}$ detoxification such as superoxide dismutase and catalase increase in OSR in biofilm cells of Candida spp. and Escherichia coli [41]. Though the ability of some Candida species to form biofilms on various medical implants has been evaluated as well as their OSR and adaptation to nutrients present in the target tissue $[13,37]$, it is however important to investigate how the carbon substrate impacts on biofilm formation by different Candida species and how sessile cells respond to antifungals and oxidative stress. These combined analyses will contribute to a better comprehension of the processes that take place in an immunocompromised patient. Here, we evaluated how $C$. albicans and three NCAC adapt to media containing different amounts of glucose during biofilm formation as well as the responses of sessile cells to antifungals, silver nanoparticles (AgNPs), and oxidative stress.

\section{Materials and Methods}

2.1. Strains and Culture Conditions. The strains of C. albicans, C. glabrata, C. krusei, and C. parapsilosis used in this study are clinical isolates from blood cultures of the collection of Departamento de Microbiología, ENCB-IPN, México, and were kindly donated by Professor M. A. Martínez Rivera. Yeast strains were cultured on yeast peptone (YP (yeast extract): $1 \%$; peptone: $2 \%$ ) or aminoacid-free yeast nitrogen base (YNB). YP and YNB media were supplemented with 0 , 0.2 , or $2 \%$ glucose (Sigma-Aldrich, USA), and $2 \%$ agar was added to solidify the media [42].
2.2. Biofilm Formation. All four Candida species were grown in $\mathrm{YPD} / 2 \%$ for $48 \mathrm{~h}$ at $28^{\circ} \mathrm{C}$. To promote biofilm formation, yeasts were harvested by low-speed centrifugation and resuspended in $100 \mu \mathrm{L}$ of the different media to a cell density of $\mathrm{OD}_{600 \mathrm{~nm}}$ 1.0. Each sample was placed into a well of flat-bottomed 96-well microtiter plates (Nunc, Nalgene) and incubated for 12,24 , or $48 \mathrm{~h}$ at $37^{\circ} \mathrm{C}$. After biofilm formation, planktonic cells were discarded by washing the wells four times with sterile $10 \mathrm{mM}$ calcium chloride $\left(\mathrm{CaCl}_{2}\right.$, Sigma-Aldrich) prepared in phosphate-buffered saline, pH 7.2 (PBS, Sigma-Aldrich). Metabolic activity of sessile cells adhered to the plastic surface (biofilm) was measured using XTT [2,3-bis(2-methoxy-4-nitro-5-sulfophenyl)2H-tetrazolium-5-carboxanilide] (Sigma-Aldrich), which is reduced by mitochondrial dehydrogenase to a watersoluble formazan that results in a colorimetric change [43]. Accordingly, $100 \mu \mathrm{L}$ of XTT-menadione $(0.1 \mathrm{mg} / \mathrm{mL}$ XTT, $1 \mu \mathrm{M}$ menadione, Sigma-Aldrich) was added to each well and plates were incubated at $37^{\circ} \mathrm{C}$. After $105 \mathrm{~min}$, the XTTderived formazan was measured at $492 \mathrm{~nm}$ using a microtiter plate reader (Varioskan Flash, Thermo Scientific). The same assay was used to determine the viability of sessile cells after exposure to different concentrations of $\mathrm{H}_{2} \mathrm{O}_{2}(0,50$, and $150 \mathrm{mM}$ for C. albicans and C. glabrata and 0,300 , and $1500 \mathrm{mM}$ for C. krusei and C. parapsilosis) or menadione (0, 2.4 and $8.4 \mathrm{mM}$ for the four Candida species). Independent assays were done in triplicate.

2.3. Scanning Electron Microscopy (SEM). Sterile polystyrene discs $(0.7 \mathrm{~cm}$ in diameter) were placed in wells of 24 -well tissue culture plates (Corning, USA). To form biofilms, $300 \mu \mathrm{L}$ of each Candida culture $\left(\mathrm{OD}_{600 \mathrm{~nm}} 1.0\right)$ was layered over the discs and plates were incubated at $37^{\circ} \mathrm{C}$. After $48 \mathrm{~h}$, free and nonadhered cells were eliminated by washing thrice with $10 \mathrm{mM} \mathrm{CaCl}_{2}$ and cells in biofilms were fixed for $3 \mathrm{~h}$ at room temperature with $4.0 \%(\mathrm{v} / \mathrm{v})$ glutaraldehyde in $0.1 \mathrm{~N}$ sodium-cacodylate buffer, pH 7.4 (Sigma-Aldrich). Fixed cells were dried for $6 \mathrm{~h}$ in a Tousimis Auto Samdri 815 Critical Point Dryer, and dry samples were covered with a layer of colloidal gold and observed with a Leica F-420 model Sigma scanning electron microscope. Images were taken using a normal electrode SE detector at $10 \mathrm{kV}$ under high vacuum conditions and at a working distance of $4 \mathrm{~mm}$.

2.4. Assay of Antifungal Susceptibility. The effect on antifungals on the four Candida species was determined on planktonic (logarithmic or stationary phases) and sessile (biofilm) cells. For cells in logarithmic phase, fresh YPD medium was inoculated to a final density of $\mathrm{OD}_{600 \mathrm{~nm}} 0.03$ and cells were allowed to grow at $28^{\circ} \mathrm{C}$ until they reached an $\mathrm{OD}_{600 \mathrm{~nm}}$ 0.1. For assays with cells in stationary phase, cultures were incubated for $48 \mathrm{~h}$ at $28^{\circ} \mathrm{C}$ and then diluted to a final density of $\mathrm{OD}_{600 \mathrm{~nm}} 0.1$ in sterile deionized water. To analyze sessile cells, $100 \mu \mathrm{L}$ of sterile deionized water was added to each prewashed well and the cells were mechanically detached using a sterile spatula. The suspension of detached sessile cells was adjusted to an $\mathrm{OD}_{600 \mathrm{~nm}} 0.1$. Sensitivity of both cell types to antifungals was determined by two methods: (a) broth microdilution assay according to the 
Clinical and Laboratory Standards Institute (CLSI) and (b) exponential dilutions of cells. Fluconazole, ketoconazole, itraconazole, and miconazole (Sigma-Aldrich) were used in both methods at final concentrations ranging from 0 to $256 \mu \mathrm{g} / \mathrm{mL}$. Antifungals were prepared in dimethyl sulfoxide (DMSO, Sigma-Aldrich) whose final concentration in all assays did not exceed $1 \%$. In the first method, yeast cells were inoculated in Petri dishes containing solid Mueller Hinton or Sabouraud media (both from Becton-Dickinson). Sterile filter paper discs (6 $\mathrm{mm}$ in diameter, Whatman) were placed over the inoculated media and $4 \mu \mathrm{L}$ of aliquots containing different concentrations of antifungals $(0.05,0.18$, $0.62,2.1,6.9,23.0,76.8$, and $256 \mu \mathrm{g} / \mathrm{mL}$ ) was added on the disc surface and plates were incubated at $37^{\circ} \mathrm{C}$. After 24-36 h, growth was inspected to determine the minimum inhibitory concentration (MIC). MIC values refer to the concentration of antifungal required to inhibit the visible growth of each Candida species. Photographs were taken with a Syngene Gene Genius Bio Imaging system. In the second method, suspensions of planktonic and sessile cells $\left(\mathrm{OD}_{600 \mathrm{~nm}}\right.$ 0.1 ) were divided into equal aliquots that were incubated with antifungals at the concentrations indicated above and shaken at $37^{\circ} \mathrm{C}$. After $90 \mathrm{~min}$, cell density was readjusted to $\mathrm{OD}_{600 \mathrm{~nm}} 0.1$ and exponential dilutions were prepared in 96-well plates and each dilution was spotted onto MuellerHinton agar plates. These were incubated at $37^{\circ} \mathrm{C}$ and growth was inspected after $48 \mathrm{~h}$.

2.5. Assay of Susceptibility to AgNPs. Cultures of planktonic (logarithmic or stationary phase) and sessile cells were adjusted to $\mathrm{OD}_{600 \mathrm{~nm}} 0.1$ and inoculated in Petri dishes containing Mueller-Hinton agar medium. Filter paper discs with antifungals were placed over the medium as described above and each disc received $20 \mu \mathrm{L}$ of AgNPs prepared according to Solomon et al. [44]. Plates were incubated at $28^{\circ} \mathrm{C}$ and photographs were taken after $24-36 \mathrm{~h}$ with a Syngene Gene Genius Bio Imaging system. Experiments were carried out in triplicate.

2.6. Assay of Susceptibility to $\mathrm{H}_{2} \mathrm{O}_{2}$ and Menadione. Equal aliquots of planktonic and sessile cells $\left(\mathrm{OD}_{600 \mathrm{~nm}} 0.5\right)$ were exposed to increasing concentrations of $\mathrm{H}_{2} \mathrm{O}_{2}$ or menadione (Sigma-Aldrich) and incubated with shaking at $28^{\circ} \mathrm{C}$. After $90 \mathrm{~min}$, the cell density of aliquots of treated cells was readjusted to $\mathrm{OD}_{600 \mathrm{~nm}} 0.5$ and used to prepare exponential dilutions in 96-well plates. Each dilution was then spotted onto YPD plates and incubated at $28^{\circ} \mathrm{C}$ for $48 \mathrm{~h}$. Photographs were taken with a Syngene Gene Genius Bio Imaging system. Experiments were carried out in quadruplicate.

2.7. Statistical Analysis. In order to maximize statistical power (minimum number of comparisons), all temporal data were summarized by using the area under the curve (AUC). This was computed for each set of data corresponding to all time points of one trial. The AUC data were analysed with a two-way ANOVA test, followed by a Bonferroni post hoc test $\left(\alpha=0.05,{ }^{*} P<0.05,{ }^{* *} P<0.01\right.$, and $\left.{ }^{* * *} P<0.001\right)$. The AUC computation (trapezoid rule) and the statistical analysis were performed with the GraphPad Prism software (Graphpad, USA).

\section{Results}

3.1. Biofilm Formation by Candida Species under Different Nutritional Conditions. To evaluate their ability to adapt during biofilm formation, the four pathogenic Candida species were grown in two different media supplemented with different glucose concentrations. After $12 \mathrm{~h}$, C. albicans formed biofilms in YPD/2\%, C. glabrata in $\mathrm{YNB}$ and $\mathrm{YNB} / 0.2 \%$, C. krusei in YP, and C. parapsilosis in both $\mathrm{YPD} / 0.2 \%$ and YPD/2\% (Figure 1(a)). After 24 h, C. albicans formed biofilms in $\mathrm{YP}, \mathrm{YPD} / 0.2 \%$, and $\mathrm{YPD} / 2 \%$ and $C$. glabrata in $\mathrm{YNB}$ and $\mathrm{YNB} / 0.2 \%$, while C. krusei and C. parapsilosis did so in YPD/0.2\% and YPD/2\% (Figure 1(b)). Results obtained after $48 \mathrm{~h}$ (Figure 1(c)) revealed that C. albicans and C. glabrata formed biofilms under the same conditions observed after 24 h, while C. krusei and C. parapsilosis preferred YNB and YP, respectively (Figures $1(\mathrm{~b})$ and $1(\mathrm{c})$ ). It was observed that cells were not able to form mature biofilms after $12 \mathrm{~h}$ probably because this corresponds to the time required for adherence to the biomaterial and the start of cell increment. To confirm that cells in wells were not just adhered to polypropylene but they represented true biofilms, sessile cells were quantified by the XTT-based method as described previously. For all species, the number of sessile cells was very low after $12 \mathrm{~h}$, but it significantly increased after longer times of incubation (Figure 2). It was also observed that C. albicans formed biofilms after 24 and $48 \mathrm{~h}$ in YPD/2\% and C. glabrata in $\mathrm{YNB}$ and $\mathrm{YNB} / 0.02 \%$, whereas C. krusei and C. parapsilosis did so in YPD/0.2\% (Figure 2). XTT reduction quantifies sessile cells of the four species of Candida in the different media and it is therefore possible to consider both factors, that is, media and species. This comparison allowed us to identify the ideal media for each species, that is, the one that results in easy adaptation and consequently efficient biofilm formation. Each assay consisted of eight time lapses between 0 and $105 \mathrm{~min}$ and six media. The temporal dynamics of the XTT assay was summarized by computing the area under the curve (trapezoidal method). This allows data reduction where each time interval $(12,24$ and $48 \mathrm{~h})$ is represented by six values for each species. Comparison of media and species was carried out by a two-way ANOVA test with $\alpha=0.05$ followed by a post hoc Bonferroni test. The highest numbers of sessile cells after 12 hours of incubation were obtained in YPD/2\% (C. albicans); in YNB/0.2\% (C. glabrata and $C$. krusei); and in YP, YPD/0.2\%, and YPD/2\% (C. parapsilosis) (Figure 3(a)). After 24 and $48 \mathrm{~h}, C$. albicans was able to develop a biofilm in YPD/2\%, while C. glabrata formed it in YNB and YNB/0.2\% (Figures 3(b) and 3(c)). C. krusei formed biofilms in YPD/0.2\% after $24 \mathrm{~h}$ (Figure $3(\mathrm{~b})$ ) and in YP, $\mathrm{YPD} / 0.2 \%$, andYPD/2\% after $48 \mathrm{~h}$. On its part, C. parapsilosis developed biofilms in YP, YPD/0.2\%, and YPD/2\% after $24 \mathrm{~h}$ (Figures 3(b) and 3(c)). In contrast with C. albicans, C. krusei and $C$. parapsilosis which preferred a rich medium such as YPD, C. glabrata preferred YNB (Figures 2 and 3).

Although data obtained in this study support the notion that each Candida species requires specific nutritional 


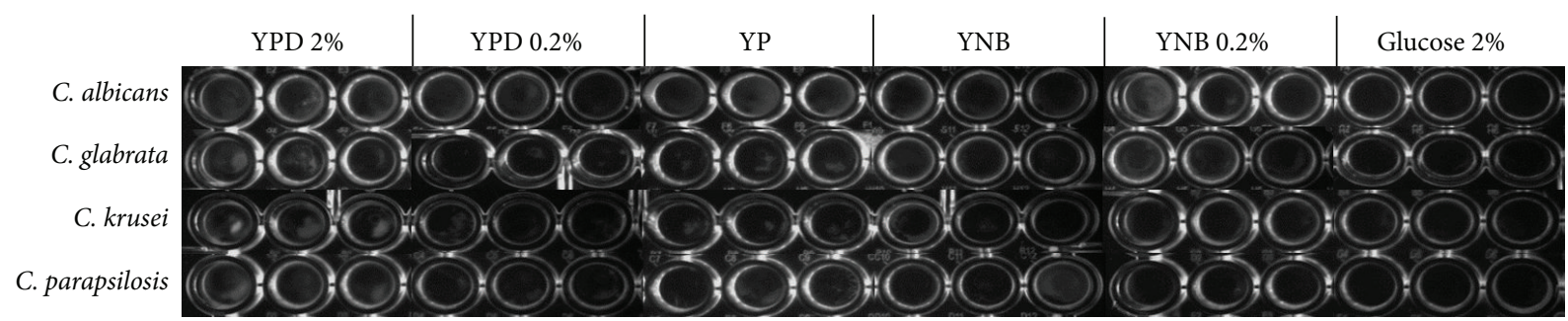

(a)

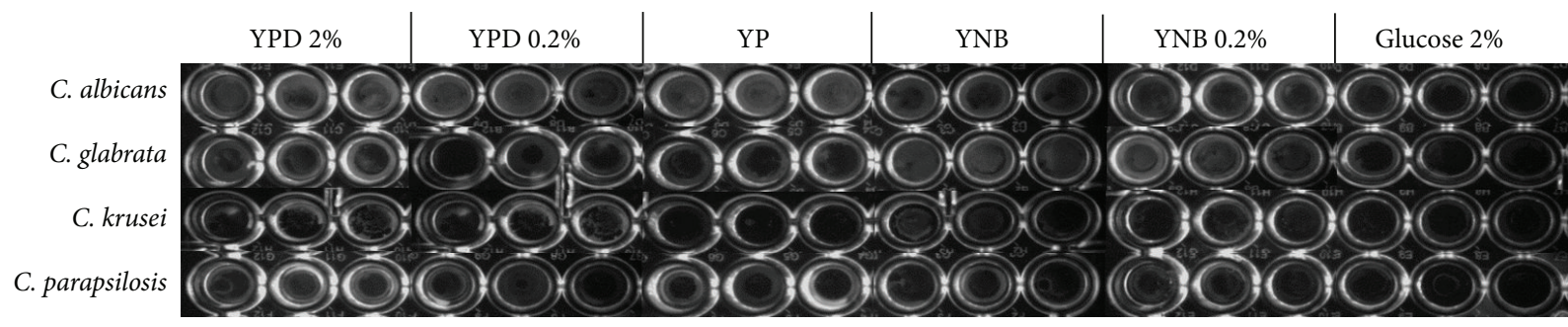

(b)

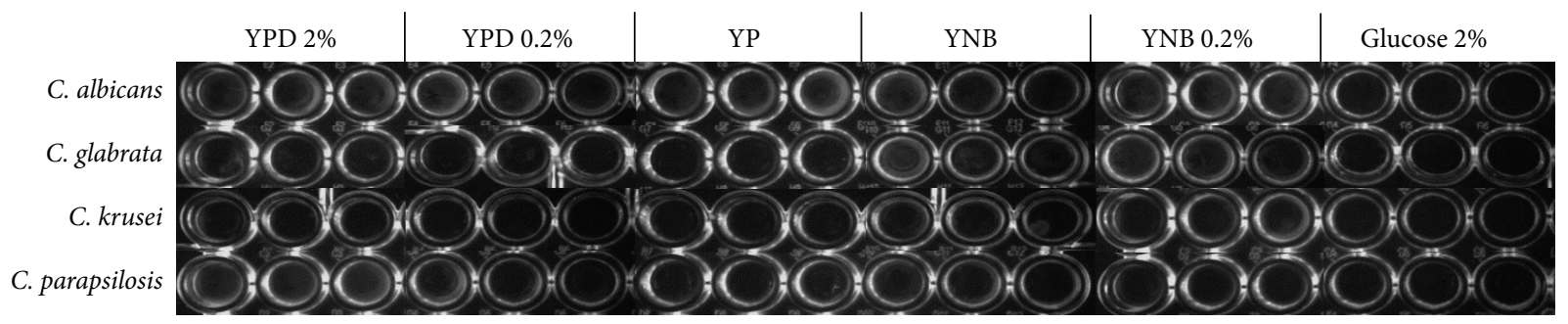

(c)

FIGURE 1: Biofilm formation by C. albicans, C. glabrata, C. krusei, and C. parapsilosis. Yeast cells grown as described in Materials and Methods were harvested by low-speed centrifugation and suspensions were adjusted to a final density of $\mathrm{OD}_{600 \mathrm{~nm}} 1.0$ in $100 \mu \mathrm{L}$ of either YP or YNB media supplemented or not, with 0.2 or $2 \%$ glucose. Cells were placed in wells of flat-bottomed 96 -well microtiter plates (Nunc, Nalgene) and incubated at $37^{\circ} \mathrm{C}$. After $12 \mathrm{~h}$ (a), $24 \mathrm{~h}$ (b), and $48 \mathrm{~h}$ (c), biofilm formation was assessed and planktonic cells were removed by washing the wells with sterile $10 \mathrm{mM}$ calcium chloride. Plates were photographed with a Syngene Gene Genius Bio Imaging system.

conditions to form biofilms, it may be necessary to include a significant number of strains of each Candida species in similar future studies to evaluate whether a correlation exist in vivo between the physiological state of the patient and the pathogens. Yet, our observations on the effect of nutritional conditions in vitro support the notion that, in vivo, each Candida species differentially adhere and colonize a physiological niche, thus resulting in the onset of infection.

3.2. Analysis of Biofilms by SEM. Biofilms formed by the four Candida species in the conditions described above were observed by SEM (Figure 4). C. albicans biofilms consisted of yeast, pseudohyphae, and hyphae cells immersed in a highly organized structure where pores with diameters in the range of $20-40 \mu \mathrm{m}$ are clearly evident as well as the presence of an exopolymeric matrix, as has been observed by other authors (Figure 4(a)) [45-47]. The biofilm formed by C. glabrata contained yeast cells only and it also exhibited pores of about $8.5 \mu \mathrm{m}$ and a less abundant exopolymeric material as compared to $C$. albicans (Figure 4(b)). The $C$. krusei biofilm also contained yeast cells, pores of about $3.0 \mu \mathrm{m}$, and residual amounts of the exopolymeric substance (Figure 4(c)) as compared to C. albicans and C. glabrata
(Figures 4(a) and 4(b)). Finally, C. parapsilosis was unable to form a biofilm and neither a considerable cell density nor an exopolymeric product (Figure 4(d)). These observations suggest that nutrients, present in the medium, as well as the ability of each species to adapt to it, influence the formation, composition, and structure of biofilms by Candida cells.

\subsection{In Vitro Effect of Azole-Based Antifungals Either Alone} or Combined with AgNPs on Planktonic and Sessile Cells of Candida Species. The functionality of biofilms formed by each Candida species was evaluated by determining their responses to azole antifungals either alone or in combination with AgNPs. In addition, two culture media such as Sabouraud (S) and Mueller-Hinton $(\mathrm{MH})$ were used to compare the susceptibility to antifungals under different growth conditions. For these assays, yeast planktonic cells in logarithmic (LP) or stationary (SP) phases were used as control as it has been demonstrated that they are more susceptible than biofilm sessile cells to antifungals [34-36]. Results shown in Figure 5 and Table 1 indicate that LP cells of $C$. albicans exhibit significant differences in resistance; accordingly, they resisted up to $256 \mu \mathrm{g}$ ketoconazole $/ \mathrm{mL}$ in $\mathrm{S}$, whereas this concentration decreased to only $2.1 \mu \mathrm{g} / \mathrm{mL}$ in 

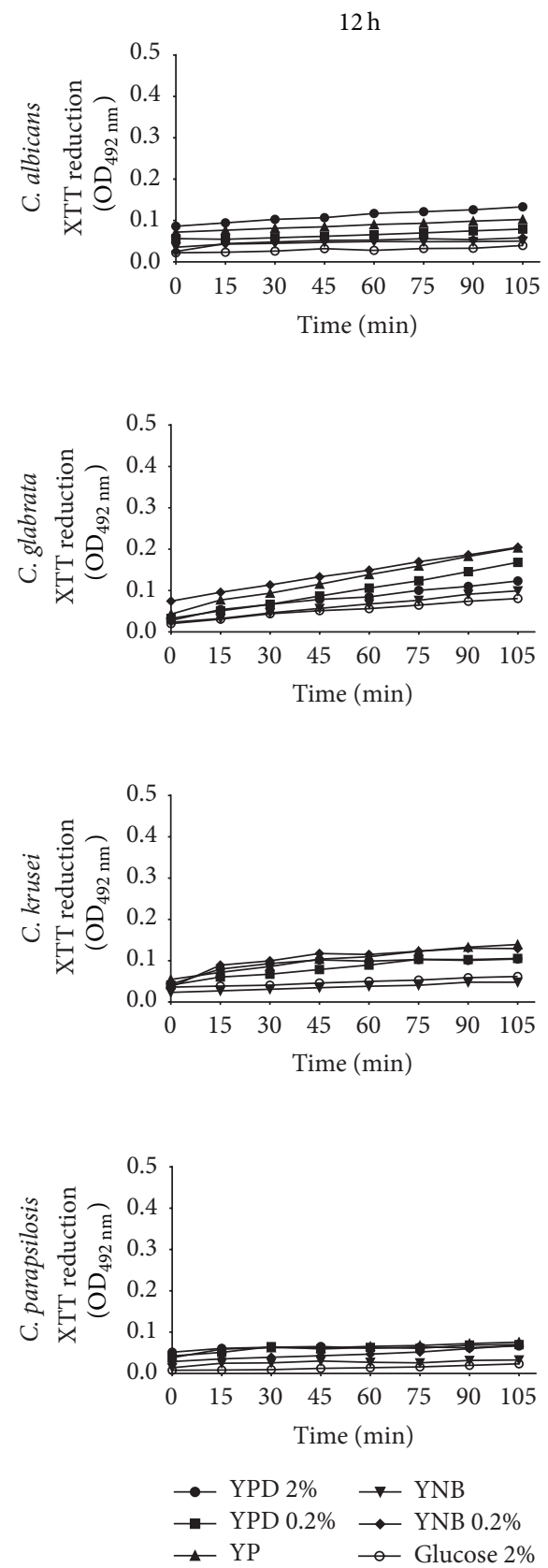

$24 \mathrm{~h}$

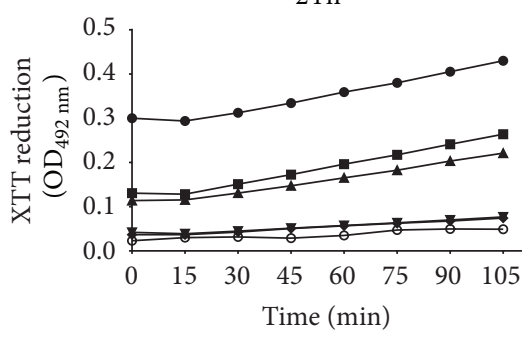

(a)

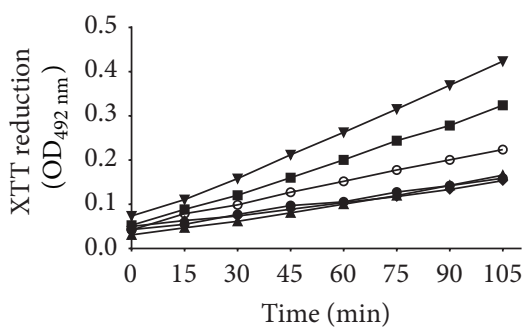

(b)

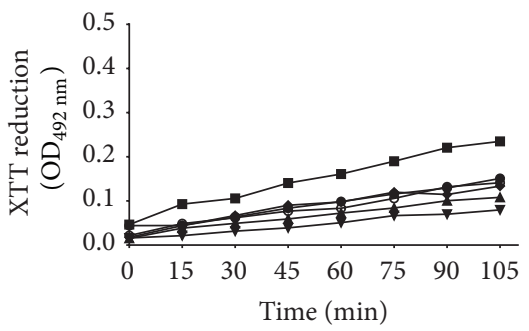

(c)

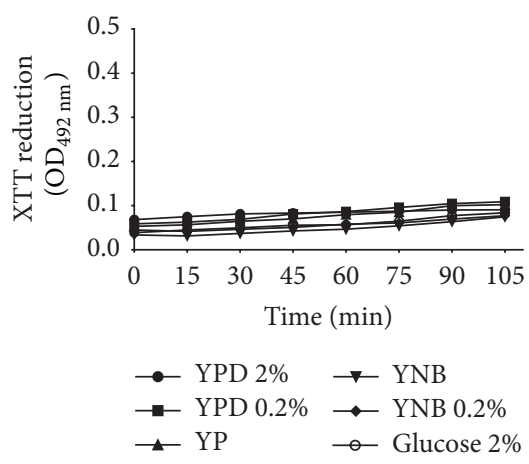

(d)
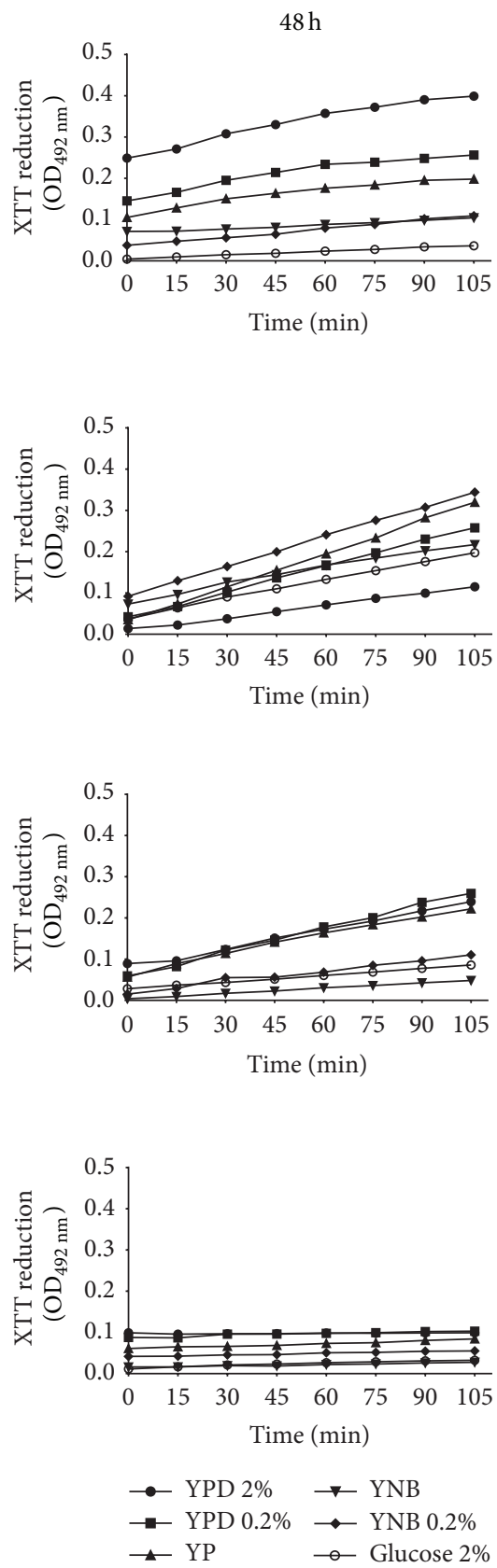

Figure 2: Temporal dynamics of sessile cells at 12,24 , and $48 \mathrm{~h}$. The viability of the four Candida species was evaluated by measuring the amount of sessile cells with XTT in six nutritional environments. The temporal dynamics of the amount of cells was evaluated at eight consecutive time points $(0,15,30,45,60,75,90$, and $105 \mathrm{~min})$ after time lapses of 12,24 , and $48 \mathrm{~h}$. The nutritional environments were YP, $\mathrm{YPD} / 0.2 \%, \mathrm{YPD} / 2 \%, \mathrm{YNB}, \mathrm{YNB} / 0.2 \%$, and YNB/2\%. Plots show the mean value at each time point (mean of 3 assays) of XTT reduction.

MH. However, in both media C. albicans was equally sensitive to miconazole $(6.9 \mu \mathrm{g} / \mathrm{mL})$ and itraconazole $(2.1 \mu \mathrm{g} / \mathrm{mL})$. On the other hand, this pathogen was over 3 -fold more susceptible to fluconazole in $\mathrm{S}$ than in $\mathrm{MH}(23$ versus $9 \mu \mathrm{g} / \mathrm{mL})$. SP yeast cells of $C$. albicans were comparably susceptible toketoconazole $(2.1 \mu \mathrm{g} / \mathrm{mL})$ and miconazole $(6.9 \mu \mathrm{g} / \mathrm{mL})$ in both media, whereas they were more resistant to itraconazole in $\mathrm{S}$ than in $\mathrm{MH}(6.9$ versus $2.1 \mu \mathrm{g} / \mathrm{mL})$. This response contrasts with the resistance shown to fluconazole, namely, up to $256 \mu \mathrm{g} / \mathrm{mL}$ in S whereas only $6.9 \mu \mathrm{g} / \mathrm{mL}$ in $\mathrm{MH}$. Noticeably, sessile cells of $C$. albicans were resistant to the four tested antifungals up to concentrations of $256 \mu \mathrm{g} / \mathrm{mL}$ in both $\mathrm{S}$ and MH media (Figure 5(a); Table 1). Sessile cells of the other three Candida species were in general more resistant to antifungals than planktonic cells (Table 1).

To determine whether sessile cells also resisted high concentrations of an antimicrobial agent, the combined effect of antifungals and AgNPs was determined. Mock incubations 


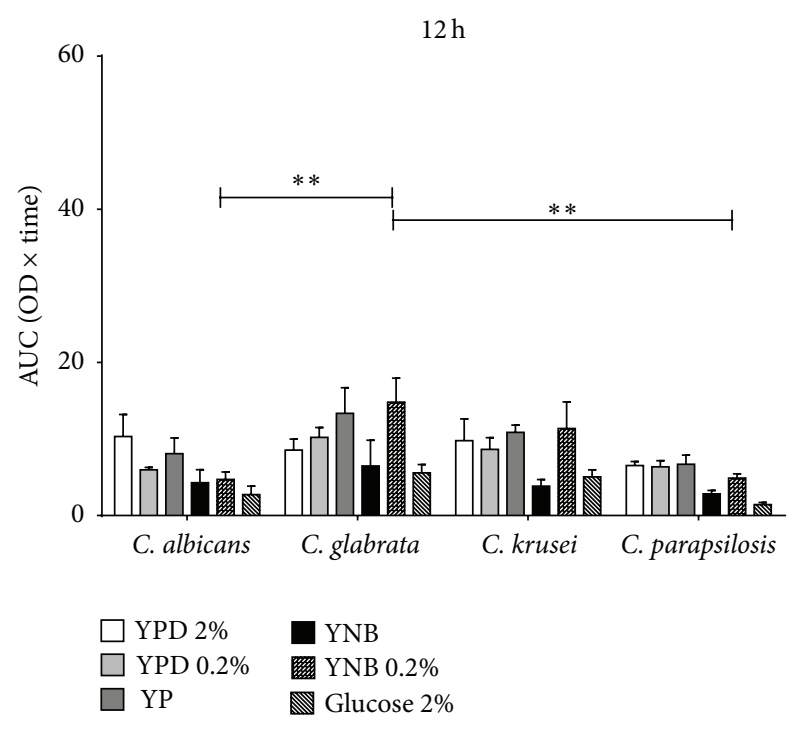

(a)

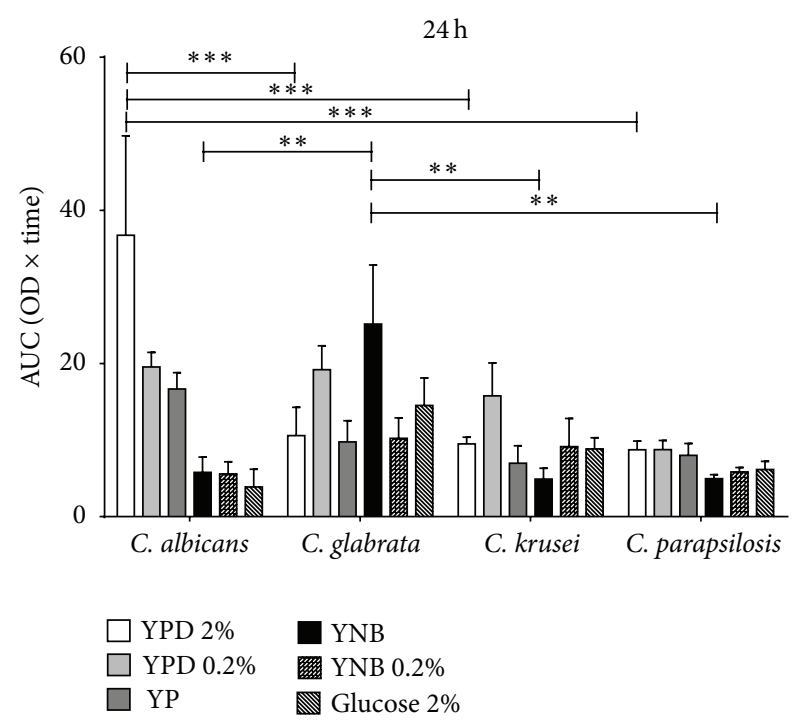

(b)

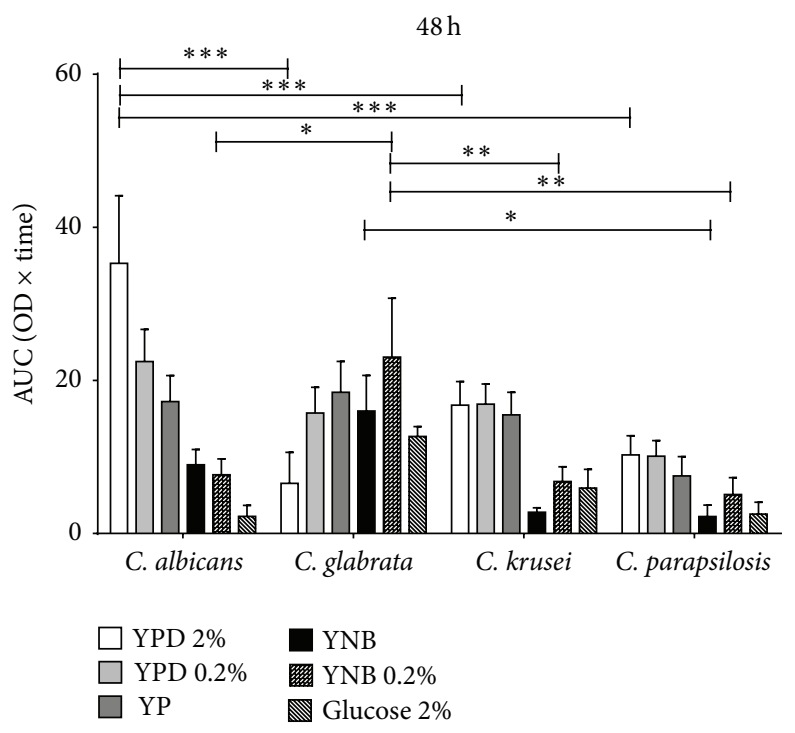

(c)

Figure 3: Area under the curve (AUC) of the amount of sessile cells. Bars represent the mean value $( \pm \mathrm{SD})$ of the area under the curve (trapezoidal rule), which was computed for the OD values of eight consecutive time points $(0,15,30,45,60,75,90$, and 105 min) at intervals of 12, 24, and $48 \mathrm{~h}$ (panels a, b, and c, resp.). For comparison among Candida species and nutritional environments, at each elapsed interval, a two-way ANOVA was performed, followed by a Bonferroni post hoc test $\left(\alpha=0.05,{ }^{*} P<0.05,{ }^{* *} P<0.01\right.$, and $\left.{ }^{* * *} P<0.001\right)$. The nutritional environments were $\mathrm{YP}, \mathrm{YPD} / 0.2 \%, \mathrm{YPD} / 2 \%, \mathrm{YNB}, \mathrm{YNB} / 0.2 \%$, and $\mathrm{YNB} / 2 \%$.

containing AgNPs only were run in parallel. Surprisingly, we observed that both sessile and planktonic cells were able to grow in the presence of the nanoparticles (Figure 5(a)) indicating that at the used concentration AgNPs are not toxic to the four Candida species. It has been described that microbicidal effect of AgNPs depends on a number of factors such as the size and form of nanoparticles, their chemical composition, the coating, and potential surface charge and concentration [48]. Results shown in Table 1 indicate that sessile but not planktonic cells of the four species were able to grow in the presence of antifungals and AgNPs. For instance, biofilm-associated cells of $C$. albicans grew in the presence of up to $23 \mu \mathrm{g} / \mathrm{mL}$ itraconazole-AgNPs, whereas corresponding planktonic cells were susceptible at $2.1 \mu \mathrm{g} / \mathrm{mL}$ (Figure 5(b)). Sessile cells of the other species were similarly resistant to antifungals (Table 1 ). In the assay of susceptibility by serial dilutions, cells are exposed to antifungals for a short period of time ( $90 \mathrm{~min}$ in this study). Representative results obtained with one Candida species are depicted in Figure 6. LP planktonic cells of C. albicans resisted up to $6.9 \mu \mathrm{g} / \mathrm{mL}$ ketoconazole, while those from SP resisted up to $256 \mu \mathrm{g} / \mathrm{mL}$, which is the same as for sessile cells (Figure 6, Table 2). Both planktonic and sessile cells of C. glabrata, C. krusei, and C. parapsilosis resisted up to 

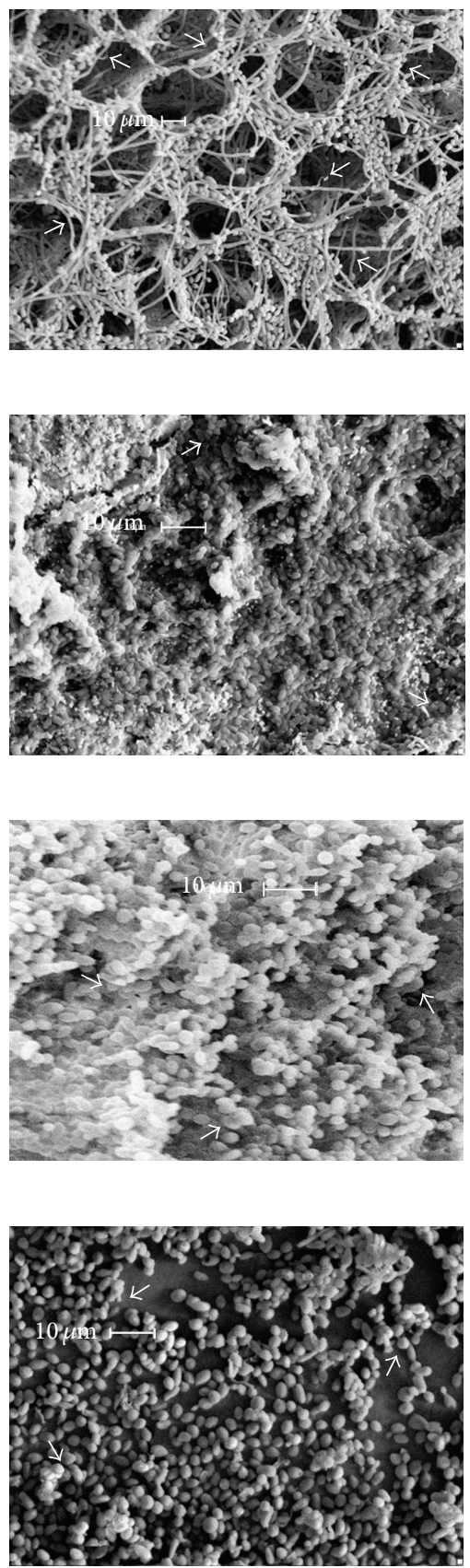

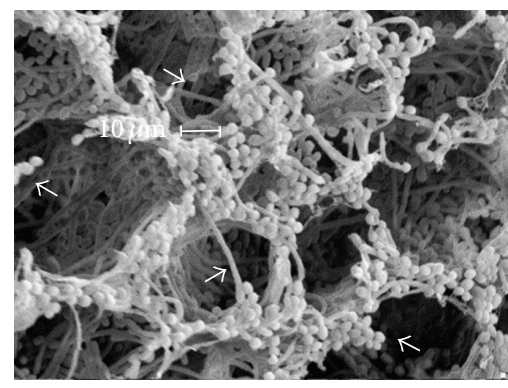

(a)

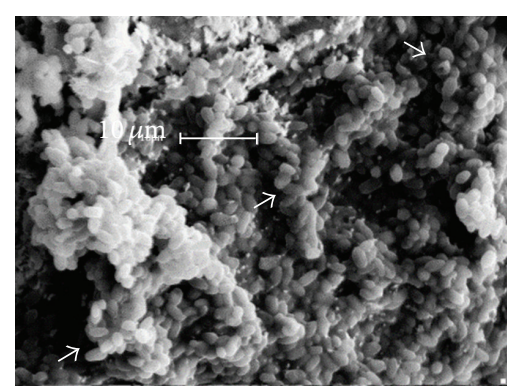

(b)

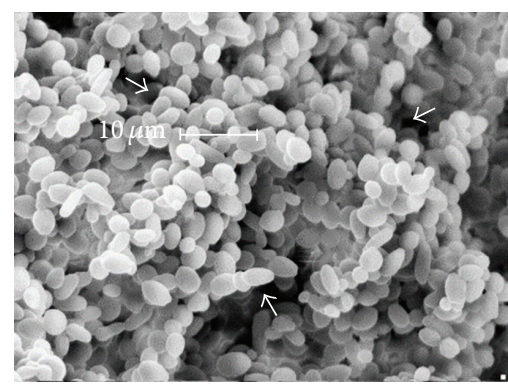

(c)

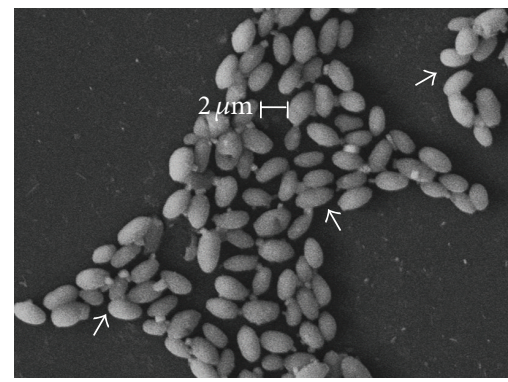

(d)
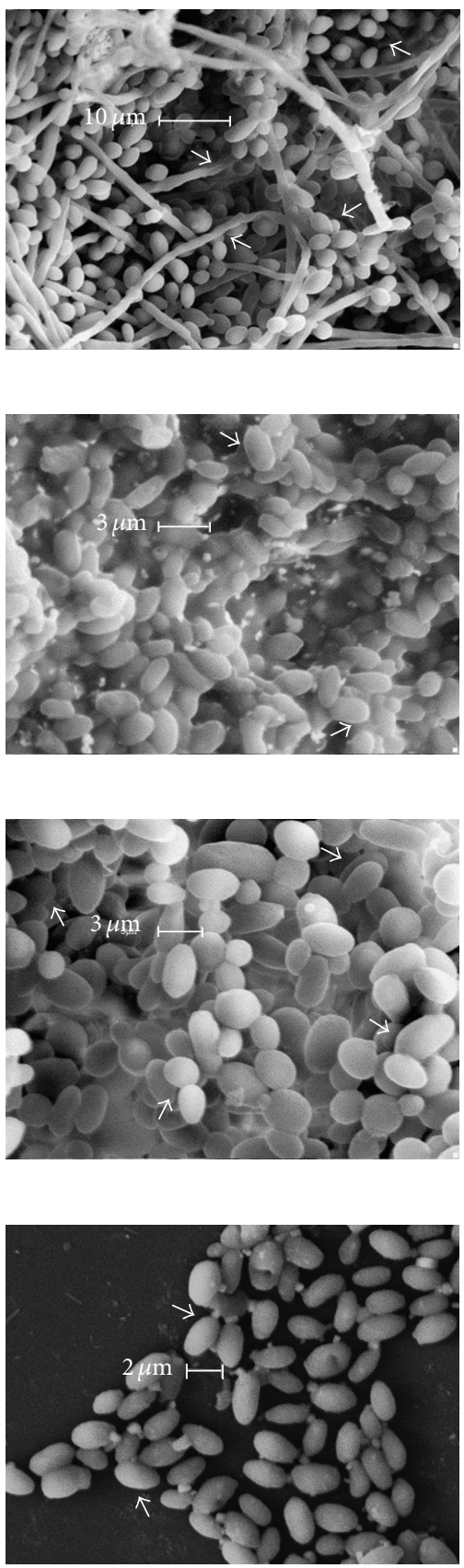

FIGURE 4: Biofilms formed by Candida species as observed by SEM. Samples were observed with a LEICA F-420 SIGMA model and scanning electron microscope using a normal electrode SE detector at $10 \mathrm{kV}$ under high vacuum conditions and at a working distance of $4 \mathrm{~mm}$. (a) $C$. albicans in YPD/2\%; (b) C. glabrata in YNB/0.2\%, (c) C. krusei in YPD/2\%, and (d) C. parapsilosis in YPD/2\%. The scale bar is indicated for each microphotography. White arrows indicate yeast, hyphae, or pseudohyphae cells.

$256 \mu \mathrm{g} / \mathrm{mL}$ fluconazole and itraconazole, but sessile cells were more resistant to ketoconazole and miconazole (Table 2). These results are in line with those observed in the other assay (longer, chronic exposure, Figure 5 and Table 1) where sessile cells were more resistant and Candida species were able to grow in the presence of high concentrations of fluconazole and itraconazole (Figure 6, Table 2).
3.4. Susceptibility of Sessile Cells of Candida Species to Oxidative Stress. It has been described that biofilm-associated cells are resistant to ROS and RNS produced during the phagocytic respiratory burst in the human host. Here, C. albicans and $C$. glabrata were able to grow in the presence of $150 \mathrm{mM} \mathrm{H}_{2} \mathrm{O}_{2}$ in contrast to the 10-fold higher resistance shown by C. krusei and C. parapsilosis (Figure 7(a)). The case of C. glabrata is of 

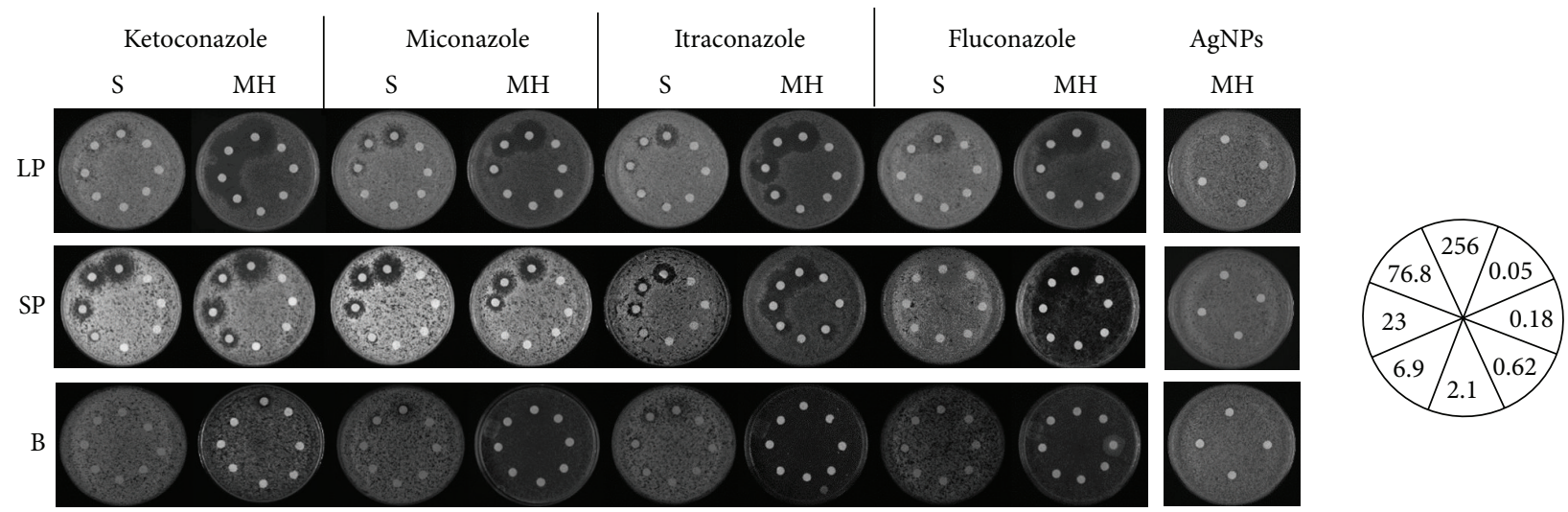

(a)
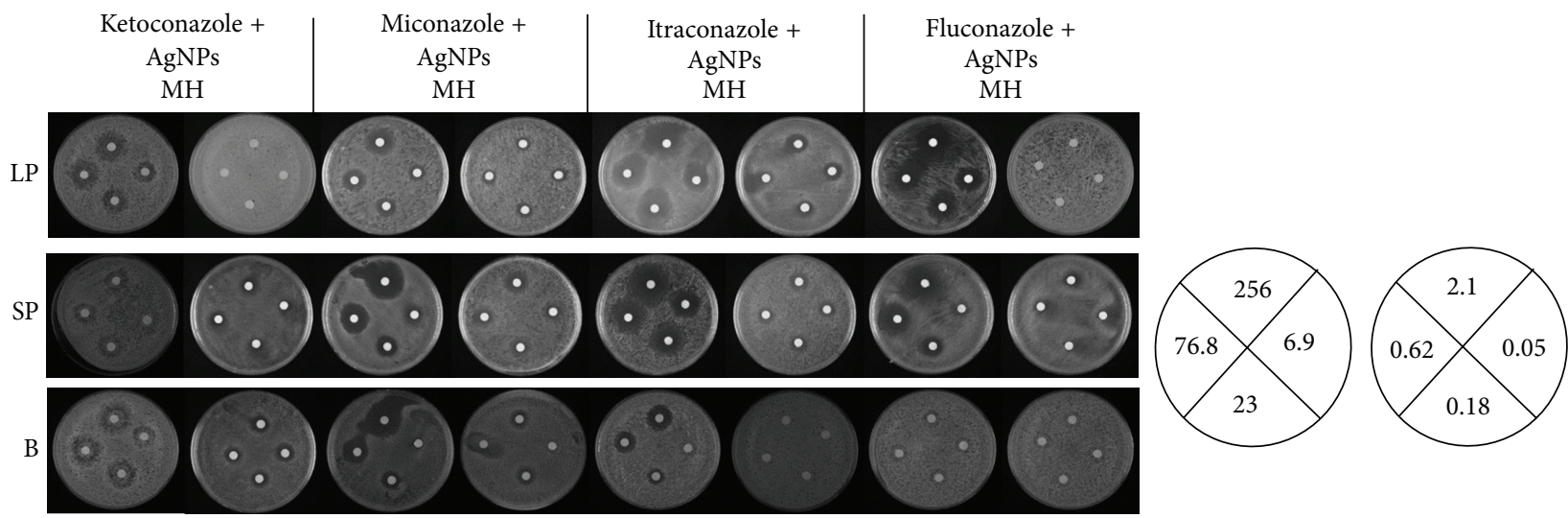

(b)

Figure 5: Susceptibility of sessile and planktonic cells to azole-derived antifungals and AgNPs. Planktonic (either from logarithmic or stationary phase) and sessile cells of $C$. albicans were diluted to an $\mathrm{OD}_{600 \mathrm{~nm}} 0.1$ with sterile deionized water. (a) Aliquots of dilutions were incubated at $37^{\circ} \mathrm{C}$ in the presence of increasing concentrations of the indicated antifungals or (b) antifungals plus AgNPs. After 90 min, cells were pelleted by low-speed centrifugation and resuspended in sterile deionized water to an $\mathrm{OD}_{600 \mathrm{~nm}} 0.1$. LP, logarithmic phase; SP, stationary phase; B, biofilm; AgNPs, silver nanoparticles; S, Sabouraud medium; MH, Mueller-Hinton medium.

special interest as we have shown that in both LP and SP this species resists higher concentrations of this oxidant than $C$. albicans $[49,50]$.

On this background, the number of viable sessile cells after exposure of Candida species to $\mathrm{H}_{2} \mathrm{O}_{2}$ was determined. Results are shown in Figure 7(b). The amount of viable cells decreased when C. albicans and C. parapsilosis were exposed to 50 and $300 \mathrm{mM} \mathrm{H}_{2} \mathrm{O}_{2}$, respectively; however, the number of cells increased after exposure of both species to a higher concentration of the oxidant. In regard to C. glabrata and C. krusei, cell viability decreased as a function of higher concentrations of oxidant.

With respect to superoxide ion, results in Figure 7 (c) indicate that C. albicans, C. glabrata, and C. krusei were able to survive up to a concentration of $8.4 \mathrm{mM}$ menadione, thus being the most resistant species to ion $\mathrm{O}_{2}{ }^{--}$. It is possible that this pathogen is able to withstand an even higher concentration of this oxidant; however, we failed to determine the minimum lethal concentration (MLC) as menadione is not soluble in DMSO at higher concentrations. In contrast to the other three species, C. parapsilosis showed less resistance and was viable up to $6.0 \mathrm{mM}$ menadione. As illustrated in
Figure 7(d), its viability decreased as a function of higher concentrations of the oxidant (Figure $7(\mathrm{~d})$ ). These results are in accord with those obtained by the dilution assay method (Figure 7(c)).

\section{Discussion}

4.1. Candida Species Can Form Biofilms under Specific Nutritional Conditions. Formation of biofilms by Candida species is a major cause of the high rates of hospital morbility and mortality [32]. During this process, the organism must adapt to some particular conditions prevailing in the target tissue including the ROS generated inside the phagolysosome. Here, we demonstrated that C. glabrata can form biofilms under rather poor nutritional conditions and a low glucose concentration in contrast to the other three species that require a rich medium such as YPD (Figures 2 and 3). This is probably due to the fact that $C$. glabrata has adapted to these conditions to preferentially colonize some human tissues and not to compete for the same physiological niche with, for instance, C. albicans. This idea is in accord with the observation that $C$. albicans is mainly isolated from 


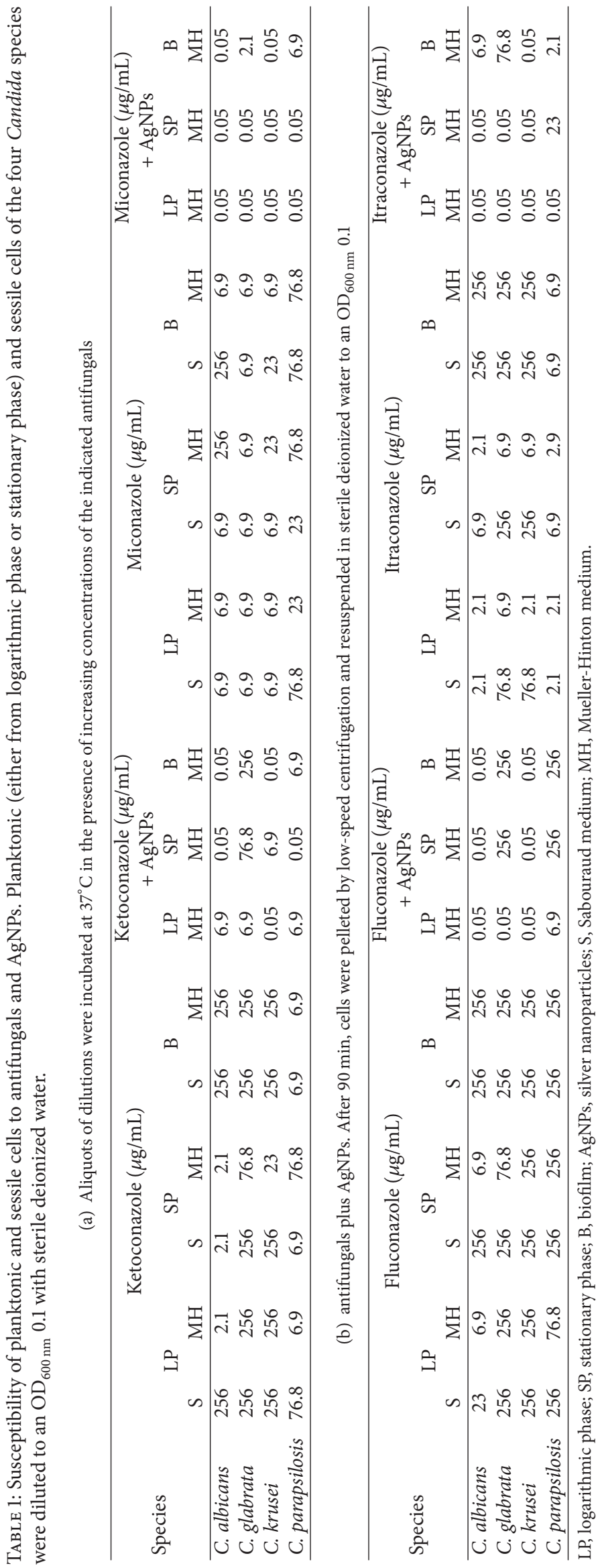


TABLE 2: Resistance of planktonic and sessile cells of Candida species to antifungals. Cultures in stationary phase of the four Candida species were diluted to an $\mathrm{OD}_{600 \mathrm{~nm}} 0.1$ with sterile deionized water. Aliquots of dilutions were incubated at $37^{\circ} \mathrm{C}$ in the presence of the indicated concentrations of antifungals. After $90 \mathrm{~min}$, water was removed by low-speed centrifugation and the corresponding cell pellets were resuspended in sterile deionized water to an $\mathrm{OD}_{600 \mathrm{~nm}} 0.1$. Samples of these suspensions were exponentially diluted in 96 -well plates and each dilution was spotted onto Mueller-Hinton agar plates that were incubated at $37^{\circ} \mathrm{C}$. Growth was inspected after $48 \mathrm{~h}$. LP, logarithmic phase; SP, stationary phase; B, biofilm.

\begin{tabular}{lcccccccccccc}
\hline \multirow{2}{*}{ Species } & \multicolumn{3}{c}{ Fluconazole $(\mu \mathrm{g} / \mathrm{mL})$} & \multicolumn{3}{c}{ Itraconazole $(\mu \mathrm{g} / \mathrm{mL})$} & \multicolumn{3}{c}{ Ketoconazole $(\mu \mathrm{g} / \mathrm{mL})$} & \multicolumn{3}{c}{ Miconazole $(\mu \mathrm{g} / \mathrm{mL})$} \\
& LP & SP & B & LP & SP & B & LP & SP & B & LP & SP & B \\
\hline C. albicans & 256 & 256 & 256 & 256 & 256 & 256 & 6.9 & 256 & 256 & 23 & 256 & 76.8 \\
C. glabrata & 256 & 256 & 256 & 256 & 256 & 256 & 23 & 76.8 & 256 & 6.9 & 76.8 & 256 \\
C. krusei & 256 & 256 & 256 & 256 & 256 & 256 & 23 & 256 & 256 & 76.8 & 256 & 256 \\
C. parapsilosis & 256 & 256 & 256 & 256 & 256 & 256 & 76.80 & 256 & 256 & 23 & 256 & 256 \\
\hline
\end{tabular}

LP SP

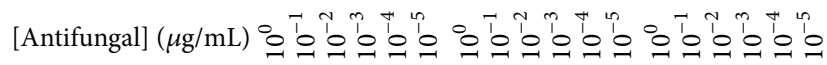

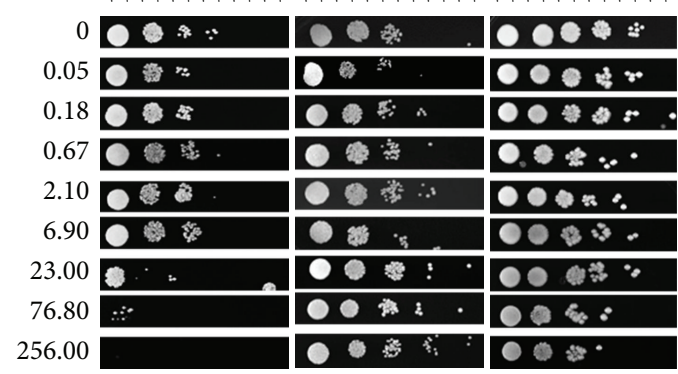

FIgURE 6: Susceptibility of planktonic and sessile cells to antifungals. Samples of cultures of $C$. albicans in stationary phase were diluted to an $\mathrm{OD}_{600 \mathrm{~nm}} 0.1$ with sterile deionized water. Aliquots of dilutions were incubated at $37^{\circ} \mathrm{C}$ in the presence of the indicated concentrations of antifungals After $90 \mathrm{~min}$, water was removed by low-speed centrifugation and the corresponding cell pellets were resuspended in sterile deionized water to an $\mathrm{OD}_{600 \mathrm{~nm}} 0.1$. Samples of these suspensions were exponentially diluted in 96-well plates and each dilution was spotted onto Mueller-Hinton agar plates that were incubated at $37^{\circ} \mathrm{C}$. Growth was inspected after $48 \mathrm{~h}$. LP, logarithmic phase; SP, stationary phase; B, biofilm.

glucose-rich environments such as the bloodstream [4-6, 8, 51]. It is not then surprising that C. albicans is the species most frequently isolated from patients suffering diabetes mellitus (DM) [52-54]. This prevalence is probably due to the finding that glucose directly promotes the resistance of $C$. albicans to antifungals, a hypothesis confirmed by experiments with diabetic mice [55]. As a consequence, administration of glucose for long periods of time to hospitalized patients may also favour tissue colonization and invasive candidiasis [56].

\subsection{Each Candida Species Forms Structurally Different} Biofilms. The differences observed in this study among biofilms formed by Candida species (Figure 4) suggest that, apart from adapting to specific nutritional conditions, each of these pathogens has developed distinct mechanisms to form biofilms and this may be related to their ability to disseminate through the bloodstream and colonize different tissues of the human body [57]. We believe that substrate requirements of each species can influence the biofilm properties. In this regard, it has been shown that galactose affects adhesion of Candida to host cells [45]. As described in other reports, $C$. albicans produces an exopolymeric matrix that consists of polysaccharides, proteins, and signalling molecules that serve the organism to distribute nutrients and as a barrier for the diffusion of antifungals into the biofilm [2, 45-47]. It has been shown that formation of the characteristic structure of $C$. albicans biofilm depends on a delicate regulation of adhesins and mannoproteins by transcriptional factors such as Bcrl, Efg1, Ndt80, Rob1, and Brg1 [58-60].

In contrast, C. glabrata, C. krusei, and C. parapsilosis produce only small amounts of exopolymeric material as observed here and by other authors $[43,61,62]$. Nonetheless, sessile cells of these pathogens resist high concentrations of antifungals (Table 1). Thus, the exopolymeric material does not contribute significantly for the survival of NCAC against antifungals. Furthermore, these findings indicate that such resistant of NCAC to azole-based antifungals might be related mainly to (1) phenotypic changes which results in poor growth or nutrient limitation and (2) the expression of resistance genes induced by the contact with the host's cells.

4.3. Sessile Cells of Candida Are More Resistant Than Corresponding Planktonic Cells to the Combined Effect of Antifungals and AgNPs. Last years have witnessed a rapid increase in the development of anti-Candida drugs and consequently to a modification in the mechanisms of resistance of these pathogens to antifungals administered to patients [63-66]. In this context, it has been reported that patients with a newly implanted medical device respond well to an antifungal therapy but after some time they develop recurrent candidiasis [67] indicating that the pathogen has formed a biofilm with a higher resistance to the treatment [68]. In line with this idea, it has been demonstrated that biofilm-associated, sessile cells can resist high concentrations of antifungals $[69,70]$, as observed also in this study when sessile cells of the four species of Candida were compared with the corresponding planktonic cells. Mechanisms of resistance may depend on (i) changes in cell wall that interfere with drug assimilation, (ii) a decrease in the affinity of the drug for its target due to either overexpression or mutation of genes coding for enzymes in the ergosterol pathway such as $14 \alpha$-lanosterol demethylase, encoded by the ERG11 gene, which is the main target of fluconazole [71-75], and (iii) an increase in the activity of 


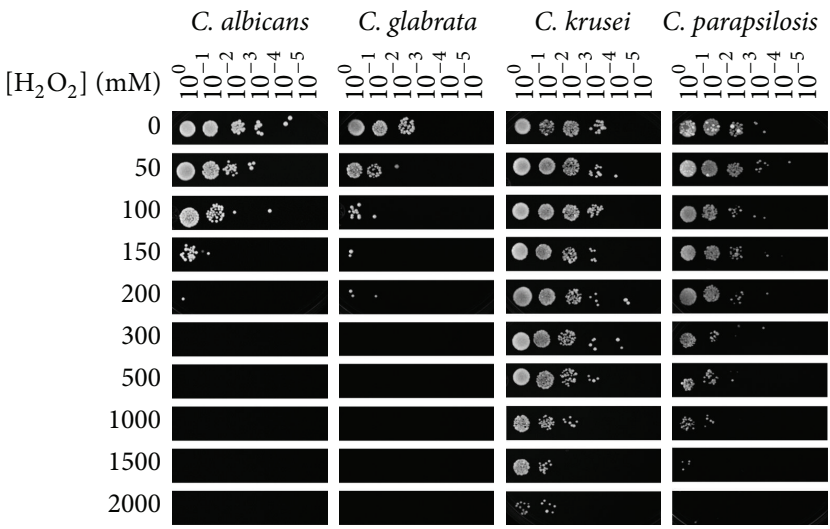

(a)

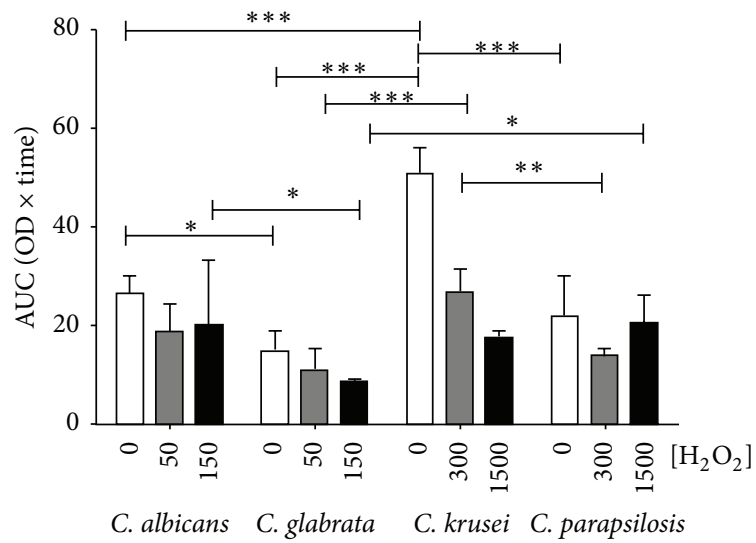

(b)

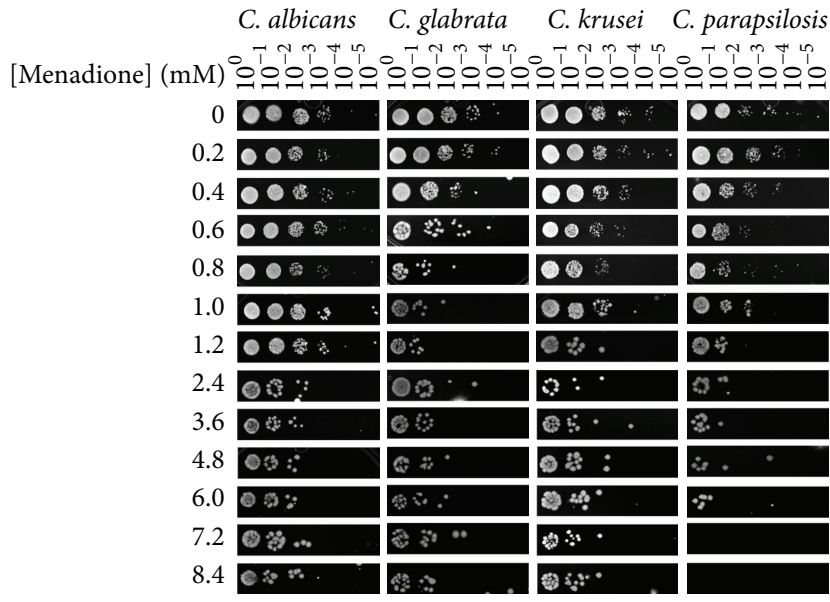

(c)

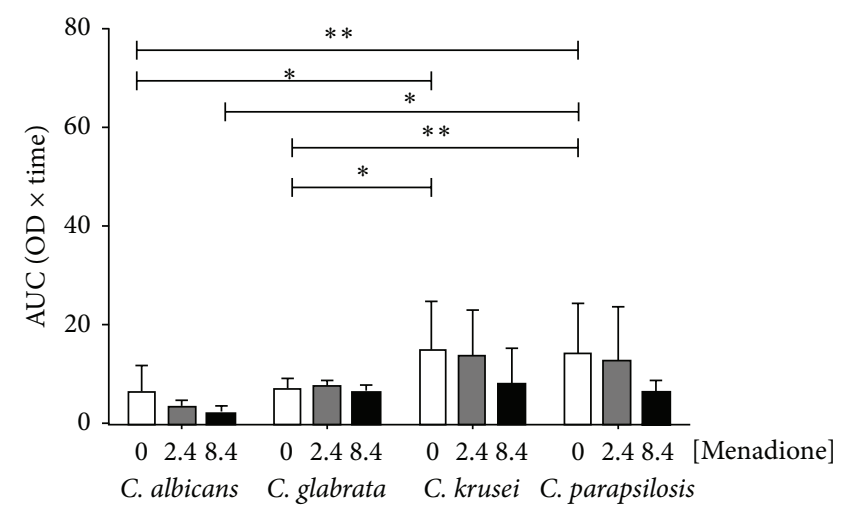

(d)

Figure 7: Response of sessile cells of Candida species to $\mathrm{H}_{2} \mathrm{O}_{2}$ and the $\mathrm{O}_{2}{ }^{--}$ion. (a, c) Sessile cells of the four Candida species were diluted to an $\mathrm{OD}_{600 \mathrm{~nm}} 0.5$ with sterile deionized water. Aliquots of dilutions were incubated at $28^{\circ} \mathrm{C}$ in the presence of the indicated concentrations of (a) $\mathrm{H}_{2} \mathrm{O}_{2}$ and (c) menadione. After $90 \mathrm{~min}$, water was removed by low-speed centrifugation and the corresponding cell pellets were resuspended in sterile deionized water to an $\mathrm{OD}_{600 \mathrm{~nm}} 0.5$. Samples of these suspensions were exponentially diluted in 96-well plates and each dilution was spotted onto YPD plates that were incubated at $28^{\circ} \mathrm{C}$. Growth was inspected after $48 \mathrm{~h}$. (b, d) Bars represent the mean value $( \pm \mathrm{SD})$ of the area under the curve (trapezoidal rule) which was computed for the OD values of eight consecutive time points $(0,15,30,45,60,75,90$, and $105 \mathrm{~min}$ ) at intervals of 12, 24, and $48 \mathrm{~h}$. For comparison among Candida species and $\mathrm{H}_{2} \mathrm{O}_{2}(\mathrm{~b})$ or menadione (d), at each elapsed interval, a two-way ANOVA was performed, followed by a Bonferroni post hoc test $\left(\alpha=0.05,{ }^{*} P<0.05,{ }^{* *} P<0.01\right.$, and $\left.{ }^{* * *} P<0.001\right)$.

membrane transport proteins involved in drug efflux $[65,71$, 72].

It was interesting to observe not only the fact that sessile cells of Candida are more resistant to antifungals but also the fact that they are able to grow in the presence of AgNPs indicating that cells in biofilms trigger mechanisms that enable them provide protection also from other antimicrobial agents.

We believe that these characteristics are the major cause of recurrent and invasive candidiasis in hospitalized and immunocompromised patients [68] that often result in fatal outcomes. We also noted that planktonic cells from the same growth phase exhibited differences in their susceptibility to antifungals depending on the culture medium, thus supporting the importance of adaptation to nutritional conditions on these responses.
Our data also indicate that both planktonic and sessile cells of the four Candida species require adaptation to the media in order to respond efficiently to the antifungals. Interestingly, once Candida has formed the biofilm, sessile cells are able to withstand high concentrations of an antifungalAgNPs mixture regardless of the media. Moreover, the fact that Candida planktonic cells are not susceptible to AgNPs (Figure 5(a)) in contrast to the response to combined AgNPs and antifungals (Figure 5(b)) suggests that these pathogens have developed mechanisms that allow them to provide protection from certain toxic compounds such as nanoparticles (NPs) at certain concentrations [48] and also that these pathogens require some other factors such as antifungals to destabilize the cell wall so AgNPs can express their microbicidal effect (Figures 5(a) and 5(b)). Furthermore, our data also support the notion that sessile cells in contrast to planktonic 
cells possess mechanisms that allow them to resist antifungals either alone or combined with other microbicides. This is in agreement with reports in other organisms such as bacteria where it has been postulated that transport of NPs perturbs cell membrane functions resulting in alterations of proteins and DNA or production of ROS in response to their presence in the cytoplasm $[48,76]$. So, for this to occur in Candida, it would be necessary that some compounds such as an antifungal alter the CW facilitating the access of NPs to the membrane to act as a microbicidal. In this regard, it has recently been described that AgNPs cannot permeate Candida cells [77]. Hopefully, this observation may help to choose other treatment alternatives such as miconazole, an azole very active against the four Candida species.

4.4. Susceptibility of Candida Species to $\mathrm{H}_{2} \mathrm{O}_{2}$ and the $\mathrm{O}_{2}{ }^{--}$Ion. The susceptibility of $C$. albicans and the resistance of $C$. krusei and C. parapsilosis to $\mathrm{H}_{2} \mathrm{O}_{2}$ (Figures $7(\mathrm{a})$ and $7(\mathrm{~b})$ ), regardless of the growth phase, are well-documented characteristics of these species [11, 49, 78]. We observed that sessile cells of $C$. glabrata are equally sensitive to this oxidant than C. albicans, which does not occur in the response of planktonic cells to oxidative stress $[11,49]$. We have also shown that cells of $C$. glabrata either in logarithmic or stationary phases are more resistant to $\mathrm{H}_{2} \mathrm{O}_{2}$ than those of $C$. albicans $[11,49]$. Nevertheless, even when sessile cells of C. albicans and C. glabrata are more sensitive to $\mathrm{H}_{2} \mathrm{O}_{2}$ than C. krusei and C. parapsilosis, they are the species that are most frequently isolated from hospitalized and immunocompromised patients.

Regarding the $\mathrm{O}_{2}{ }^{--}$ion, it has been demonstrated that resistance of planktonic cells of $C$. albicans to high concentrations of superoxide, in contrast to those C. glabrata and C. krusei which are more susceptible, is mostly due to its ability to detoxify this oxidant [12]. Here, we observed that sessile cells of $C$. albicans maintain the natural resistance to this superoxide, while those C. glabrata, C. krusei, and C. parapsilosis resist higher concentrations of $\mathrm{O}_{2}{ }^{--}$ion than corresponding planktonic cells (Figures $7(\mathrm{c})$ and $7(\mathrm{~d})$ ) [12, 50]. This is interesting as it indicates that biofilm formation favours the resistance of these pathogens to antifungals and ROS meaning that in vivo it can help their prevalence and dissemination in the human host.

\section{Conclusions}

To our knowledge, this is the first report on the relevance of nutritional conditions and glucose on the formation of biofilms by four species of Candida. In general, sessile cells are more resistant to high concentrations of antifungals and oxidative stress. This indicates that infection by these pathogens is a multifactorial process involving adaptation to particular conditions in target tissues and the human immune system, factors that should be considered during prevention and treatment of invasive mycosis. Daily administration of nutrients such as serum/glucose favours infections by most of the pathogenic species of Candida. The design and synthesis of new antifungals administered by short periods of time to prevent Candida from adaptation and thus formation of biofilms are the most desirable tasks to come up in the near future with a more efficient therapy.

\section{Conflict of Interests}

The authors declare that there was no conflict of interests with any organization or entity with a financial interest or financial conflict with the material discussed in this work.

\section{Acknowledgments}

The authors are grateful to M. en C. Dolores ÁlvarezGasca, Dr. Armando Obregón-Herrera, and Dr. Ramón Zárraga-Núñez for the technical facilities and valuable support provided to carry out this work. We are thankful for the financial support provided by Proyecto-InstitucionalUGTO-id202/2013 from the Universidad de Guanajuato, México, and PROMEP-UGTO-PTC-328 granted to Dr. M. Cuéllar-Cruz, respectively.

\section{References}

[1] R. A. Calderone and C. J. Clancy, Eds., Candida and Candidiasis, ASM Press, Washington, DC, USA, 2011.

[2] M. Cuéllar-Cruz, A. Vega-González, B. Mendoza-Novelo et al., "The effect of biomaterials and antifungals on biofilm formation by Candida species: a review," European Journal of Clinical Microbiology and Infectious Diseases, vol. 31, no. 10, pp. 25132527, 2012.

[3] R. A. Calderone and W. A. Fonzi, "Virulence factors of Candida albicans," Trends in Microbiology, vol. 9, no. 7, pp. 327-335, 2001.

[4] I. V. Ene, C. J. Heilmann, A. G. Sorgo et al., "Carbon sourceinduced reprogramming of the cell wall proteome and secretome modulates the adherence and drug resistance of the fungal pathogen Candida albicans," Proteomics, vol.12, no. 21, pp. 31643179, 2012.

[5] I. V. Ene, S.-C. Cheng, M. G. Netea, and A. J. P. Brown, "Growth of Candida albicans cells on the physiologically relevant carbon source lactate affects their recognition and phagocytosis by immune cells," Infection and Immunity, vol. 81, no. 1, pp. 238248, 2013.

[6] A. J. P. Brown, S. Budge, D. Kaloriti et al., "Stress adaptation in a pathogenic fungus," Journal of Experimental Biology, vol. 217, no. 1, pp. 144-155, 2014.

[7] A. J. P. Brown, F. C. Odds, and N. A. R. Gow, "Infectionrelated gene expression in Candida albicans," Current Opinion in Microbiology, vol. 10, no. 4, pp. 307-313, 2007.

[8] S. Vylkova, A. J. Carman, H. A. Danhof, J. R. Collette, H. Zhou, and M. C. Lorenz, "The fungal pathogen Candida albicans autoinduces hyphal morphogenesis by raising extracellular $\mathrm{pH}$," mBio, vol. 2, no. 3, Article ID e00055-11, 2011.

[9] R. C. Silva, A. C. Padovan, D. C. Pimenta, R. C. Ferreira, C. V. da Silva, and M. R. Briones, "Extracellular enolase of Candida albicans is involved in colonization of mammalian intestinal epithelium," Frontiers in Cellular and Infection Microbiology, vol. 4, article 19, 2014.

[10] A.-R. Colina, F. Aumont, N. Deslauriers, P. Belhumeur, and L. De Repentigny, "Evidence for degradation of gastrointestinal mucin by Candida albicans secretory aspartyl proteinase," Infection and Immunity, vol. 64, no. 11, pp. 4514-4519, 1996. 
[11] M. Cuéllar-Cruz, M. Briones-Martin-del-Campo, I. CañasVillamar et al., "High resistance to oxidative stress in the fungal pathogen Candida glabrata is mediated by a single catalase, Ctalp, and is controlled by the transcription factors Yaplp, Skn7p, Msn2p, and Msn4p," Eukaryotic Cell, vol. 7, no. 5, pp. 814-825, 2008.

[12] M. Cuéllar-Cruz, I. Castaño, O. Arroyo-Helguera, and A. de las Peñas, "Oxidative stress response to menadione and cumene hydroperoxide in the opportunistic fungal pathogen Candida glabrata," Memorias do Instituto Oswaldo Cruz, vol. 104, no. 4, pp. 649-654, 2009.

[13] S. C. Deorukhkar, S. Saini, and S. Mathew, "Virulence factors contributing to pathogenicity of Candida tropicalis and its antifungal susceptibility profile," International Journal of Microbiology, vol. 2014, Article ID 456878, 6 pages, 2014.

[14] S. Deorukhkar and S. Saini, "Non albicans Candida species: its isolation pattern, species distribution, virulence factors and antifungal susceptibility profile," International Journal of Medical Science and Public Health, vol. 2, pp. 533-538, 2013.

[15] C. Rodrigo Cruz and L. Eduardo Piontelli, "Invasive fungal disease in patients from five hospitals in the Valparaiso Region, Chile. 2004 to 2009," Revista Chilena de Infectologia, vol. 28, no. 2, pp. 123-129, 2011.

[16] S. Silva, M. Negri, M. Henriques, R. Oliveira, D. W. Williams, and J. Azeredo, "Candida glabrata, Candida parapsilosis and Candida tropicalis: Biology, epidemiology, pathogenicity and antifungal resistance," FEMS Microbiology Reviews, vol. 36, no. 2, pp. 288-305, 2012.

[17] A. Bedini, C. Venturelli, C. Mussini et al., "Epidemiology of candidaemia and antifungal susceptibility patterns in an Italian tertiary-care hospital," Clinical Microbiology and Infection, vol. 12, no. 1, pp. 75-80, 2006.

[18] M. A. Pfaller, R. N. Jones, S. A. Messer, M. B. Edmond, and R. P. Wenzel, "National surveillance of nosocomial blood stream infection due to Candida albicans: frequency of occurrence and antifungal susceptibility in the SCOPE program," Diagnostic Microbiology and Infectious Disease, vol. 31, no. 1, pp. 327-332, 1998.

[19] A. M. Tortorano, C. Kibbler, J. Peman, H. Bernhardt, L. Klingspor, and R. Grillot, "Candidaemia in Europe: epidemiology and resistance," International Journal of Antimicrobial Agents, vol. 27, no. 5, pp. 359-366, 2006.

[20] H. Alonso-Valle, O. Acha, J. D. García-Palomo, C. FariñasÁlvarez, C. Fernández-Mazarrasa, and M. C. Fariñas, "Candidemia in a tertiary care hospital: epidemiology and factors influencing mortality," European Journal of Clinical Microbiology and Infectious Diseases, vol. 22, no. 4, pp. 254-257, 2003.

[21] R. Ben-Abraham, N. Keller, N. Teodorovitch et al., "Predictors of adverse outcome from candidal infection in a tertiary care hospital," Journal of Infection, vol. 49, no. 4, pp. 317-323, 2004.

[22] J. Garbino, L. Kolarova, P. Rohner, D. Lew, P. Pichna, and D. Pittet, "Secular trends of candidemia over 12 years in adult patients at a tertiary care hospital," Medicine, vol. 81, no. 6, pp. 425-433, 2002.

[23] J. Garbino, D. P. Lew, S. Hugonnet, R. Auckenthaler, and D. Pittet, "Prevention of severe Candida infections in nonneutropenic, high-risk, critically ill patients: a randomized, doubleblind, placebo-controlled trial in patients treated by selective digestive decontamination," Intensive Care Medicine, vol. 28, no. 12, pp. 1708-1717, 2002.
[24] M. A. Pfaller and D. J. Diekema, "Epidemiology of invasive candidiasis: a persistent public health problem," Clinical Microbiology Reviews, vol. 20, no. 1, pp. 133-163, 2007.

[25] D. Swinne, M. Watelle, M. Van Der Flaes, and N. Nolard, "In vitro activities of voriconazole (UK-109, 496), fluconazole, itraconazole and amphotericin B against 132 non-albicans bloodstream yeast isolates (CANARI study)," Mycoses, vol. 47, no. 5-6, pp. 177-183, 2004.

[26] R. J. Kothavade, M. M. Kura, A. G. Valand, and M. H. Panthaki, "Candida tropicalis: its prevalence, pathogenicity and increasing resistance to fluconazole," Journal of Medical Microbiology, vol. 59, no. 8, pp. 873-880, 2010.

[27] C. A. Hitchcock, G. W. Pye, P. F. Troke, E. M. Johnson, and D. W. Warnock, "Fluconazole resistance in Candida glabrata," Antimicrobial Agents and Chemotherapy, vol. 37, no. 9, pp. 19621965, 1993.

[28] M. T. Durán, D. Velasco, D. Canle, R. Moure, and R. Villanueva, "Antifungal susceptibility of Candida spp. isolates from blood cultures in a five-year period (1997-2001)," Enfermedades Infecciosas y Microbiologia Clinica, vol. 21, no. 9, pp. 488-492, 2003.

[29] M. C. Furlaneto, J. F. Rota, R. M. B. Quesada et al., "Species distribution and in vitro fluconazole susceptibility of clinical Candida isolates in a Brazilian tertiary-care hospital over a 3-year period," Revista da Sociedade Brasileira de Medicina Tropical, vol. 44, no. 5, pp. 595-599, 2011.

[30] A. F. Schmalreck, B. Willinger, G. Haase et al., "Species and susceptibility distribution of 1062 clinical yeast isolates to azoles, echinocandins, flucytosine and amphotericin B from a multicentre study," Mycoses, vol. 55, no. 3, pp. e124-e137, 2012.

[31] S. B. de Paula, T. F. Bartelli, V. di Raimo et al., "Effect of eugenol on cell surface hydrophobicity, adhesion, and biofilm of Candida tropicalis and Candida dubliniensis isolated from oral cavity of HIV-infected patients," Evidence-Based Complementary and Alternative Medicine, vol. 2014, Article ID 505204, 8 pages, 2014.

[32] M. Tumbarello, B. Fiori, E. M. Trecarichi et al., "Risk factors and outcomes of candidemia caused by biofilm-forming isolates in a tertiary care hospital," PLoS ONE, vol. 7, no. 3, Article ID e33705, 2012.

[33] P. Uppuluri, A. K. Chaturvedi, A. Srinivasan et al., "Dispersion as an important step in the Candida albicans biofilm developmental cycle," PLoS Pathogens, vol. 6, no. 3, Article ID e1000828, 2010.

[34] G. Ramage, K. V. Walle, B. L. Wickes, and J. L. López-Ribot, "Biofilm formation by Candida dubliniensis," Journal of Clinical Microbiology, vol. 39, no. 9, pp. 3234-3240, 2001.

[35] F. C. Bizerra, C. V. Nakamura, C. de Poersch et al., "Characteristics of biofilm formation by Candida tropicalis and antifungal resistance," FEMS Yeast Research, vol. 8, no. 3, pp. 442-450, 2008.

[36] A. S. Melo, F. C. Bizerra, E. Freymüller, B. A. Arthington-Skaggs, and A. L. Colombo, "Biofilm production and evaluation of antifungal susceptibility amongst clinical Candida spp. isolates, including strains of the Candida parapsilosis complex," Medical Mycology, vol. 49, no. 3, pp. 253-262, 2011.

[37] C. J. Nobile, E. P. Fox, N. Hartooni et al., "A histone deacetylase complex mediates biofilm dispersal and drug resistance in Candida albicans," mBio, vol. 5, no. 3, pp. e01201-e01214, 2014.

[38] M. T. Nieminen, L. Novak-Frazer, V. Rautemaa et al., "A novel antifungal is active against Candida albicans biofilms and inhibits mutagenic acetaldehyde production in vitro," PLoS ONE, vol. 9, no. 5, Article ID e97864, 2014. 
[39] A. Katragkou, M. J. Kruhlak, M. Simitsopoulou et al., "Interactions between human phagocytes and Candida albicans biofilms alone and in combination with antifungal agents," Journal of Infectious Diseases, vol. 201, no. 12, pp. 1941-1949, 2010.

[40] K. Lewis, "Multidrug tolerance of biofilms and persister cells," Current Topics in Microbiology and Immunology, vol. 322, pp. 107-131, 2008.

[41] C. Y. Leung, Y. C. Chan, L. P. Samaranayake, and C. J. Seneviratne, "Biocide resistance of Candida and Escherichia coli biofilms is associated with higher antioxidative capacities," Journal of Hospital Infection, vol. 81, no. 2, pp. 79-86, 2012.

[42] F. Ausubel, R. Brent, R. E. Kingston et al., Current Protocols in Molecular Biology, John Wiley \& Sons, New York, NY, USA, 2001.

[43] I. Iraqui, S. Garcia-Sanchez, S. Aubert et al., "The Yaklp kinase controls expression of adhesins and biofilm formation in Candida glabrata in a Sir4p-dependent pathway," Molecular Microbiology, vol. 55, no. 4, pp. 1259-1271, 2005.

[44] S. D. Solomon, M. Bahadory, A. V. Jeyarajasingam, S. A. Rutkowsky, C. Boritz, and L. Mulfinger, "Synthesis and study of silver nanoparticles," Journal of Chemical Education, vol. 84, no. 2, pp. 322-325, 2007.

[45] G. S. Baillie and L. J. Douglas, "Matrix polymers of Candida biofilms and their possible role in biofilm resistance to antifungal agents," Journal of Antimicrobial Chemotherapy, vol. 46, no. 3, pp. 397-403, 2000.

[46] J. Chandra, D. M. Kuhn, P. K. Mukherjee, L. L. Hoyer, T. McCormick, and M. A. Ghannoum, "Biofilm formation by the fungal pathogen Candida albicans: development, architecture, and drug resistance," Journal of Bacteriology, vol. 183, no. 18, pp. 5385-5394, 2001.

[47] L. J. Douglas, "Candida biofilms and their role in infection," Trends in Microbiology, vol. 11, no. 1, pp. 30-36, 2003.

[48] M. J. Hajipour, K. M. Fromm, A. Akbar Ashkarran et al., "Antibacterial properties of nanoparticles," Trends in Biotechnology, vol. 30, no. 10, pp. 499-511, 2012.

[49] M. Cuéllar-Cruz, G. Gutiérrez-Sánchez, E. López-Romero, E. Ruiz-Baca, J. C. Villagómez-Castro, and L. Rodríguez-Sifuentes, "Identification of Candida albicans heat shock proteins and Candida glabrata and Candida krusei enolases involved in the response to oxidative stress," Central European Journal of Biology, vol. 8, no. 4, pp. 337-345, 2013.

[50] M. D. Ramírez-Quijas, R. Zazueta-Sandoval, A. ObregónHerrera, E. López-Romero, and M. Cuéllar-Cruz, "Candida species undergo dramatic changes in cell morphology in response to oxidative stress," Submitted.

[51] R. Khatib, K. M. Riederer, J. Ramanathan, and J. Baran Jr., "Faecal fungal flora in healthy volunteers and inpatients," Mycoses, vol. 44, no. 5-6, pp. 151-156, 2001.

[52] L. S. A. Gunther, H. P. R. Martins, F. Gimenes, A. L. P. de Abreu, M. E. L. Consolaro, and T. I. E. Svidzinski, "Prevalence of Candida albicans and non-albicans isolates from vaginal secretions: comparative evaluation of colonization, vaginal candidiasis and recurrent vaginal Candidiasis in diabetic and non-diabetic women," Sao Paulo Medical Journal, vol. 132, no. 2, pp. 116-120, 2014.

[53] J. Premkumar, P. Ramani, T. Chandrasekar, A. Natesan, and P. Premkumar, "Detection of species diversity in oral candida colonization and anti-fungal susceptibility among non-oral habit adult diabetic patients," Journal of Natural Science, Biology and Medicine, vol. 5, no. 1, pp. 148-154, 2014.
[54] S. Vaidyanathan, B. Soni, P. Hughes et al., "Candida albicans fungaemia following traumatic urethral catheterisation in a paraplegic patient with diabetes mellitus and candiduria treated by caspofungin," Case Reports in Infectious Diseases, vol. 2013, Article ID 693480, 6 pages, 2013.

[55] S. M. Mandal, D. Mahata, L. Migliolo et al., "Glucose directly promotes antifungal resistance in the fungal pathogen, Candida spp," The Journal of Biological Chemistry, vol. 289, pp. 2546825473, 2014.

[56] M. T. Korytkowski, "In-patient management of diabetes: controversies and guidelines," Indian Journal of Endocrinology and Metabolism, vol. 17, pp. S630-S635, 2013.

[57] M. Cuéllar-Cruz, E. López-Romero, and G. Quindós, "Invasive candidiasis: epidemiology, diagnosis and treatment," in Candidiasis: Epidemiology, Symptoms and Treatment Options, Nova Science, New York, NY, USA, 2013.

[58] C. J. Nobile and A. P. Mitchell, "Regulation of cell-surface genes and biofilm formation by the C. albicans transcription factor Bcrlp," Current Biology, vol. 15, no. 12, pp. 1150-1155, 2005.

[59] G. Ramage, K. VandeWalle, J. L. López-Ribot, and B. L. Wickes, "The filamentation pathway controlled by the Efg1 regulator protein is required for normal biofilm formation and development in Candida albicans," FEMS Microbiology Letters, vol. 214, no. 1, pp. 95-100, 2002.

[60] C. J. Nobile, E. P. Fox, J. E. Nett et al., "A recently evolved transcriptional network controls biofilm development in Candida albicans," Cell, vol. 148, no. 1-2, pp. 126-138, 2012.

[61] C. A. Kumamoto, "Candida biofilms," Current Opinion in Microbiology, vol. 5, no. 6, pp. 608-611, 2002.

[62] J. H. Shin, S. J. Kee, M. G. Shin et al., "Biofilm production by isolates of Candida species recovered from nonneutropenic patients: comparison of bloodstream isolates with isolates from other sources," Journal of Clinical Microbiology, vol. 40, no. 4, pp. 1244-1248, 2002.

[63] R. D. Cannon, F. J. Fischer, K. Niimi, M. Niimi, and M. Arisawa, "Drug pumping mechanisms in Candida albicans," Japanese Journal of Medical Mycology, vol. 39, no. 2, pp. 73-78, 1998.

[64] P. Marichal, L. Koymans, S. Willemsens et al., "Contribution of mutations in the cytochrome P450 14 $\alpha$-demethylase (Erg11p, Cyp51p) to azole resistance in Candida albicans," Microbiology, vol. 145 , no. 10 , pp. 2701-2713, 1999.

[65] T. C. White, "Increased mRNA levels of ERG16, CDR, and MDR1 correlate, with increases in azole resistance in Candida albicans isolates from a patient infected with human immunodeficiency virus," Antimicrobial Agents and Chemotherapy, vol. 41, no. 7, pp. 1482-1487, 1997.

[66] T. C. White, S. Holleman, F. Dy, L. F. Mirels, and D. A. Stevens, "Resistance mechanisms in clinical isolates of Candida albicans," Antimicrobial Agents and Chemotherapy, vol. 46, no. 6, pp. 1704-1713, 2002.

[67] N. N. Mishra, T. Prasad, N. Sharma et al., "Pathogenicity and drug resistance in Candida albicans and other yeast species," Acta Microbiologica et Immunologica Hungarica, vol. 54, no. 3, pp. 201-235, 2007.

[68] A. R. Holmes, Y.-H. Lin, K. Niimi et al., "ABC transporter Cdrlp contributes more than $\mathrm{Cdr} 2 \mathrm{p}$ does to fluconazole efflux in fluconazole-resistant Candida albicans clinical isolates," Antimicrobial Agents and Chemotherapy, vol. 52, no. 11, pp. 3851-3862, 2008.

[69] E. M. Maiolo, U. F. Tafin, O. Borens, and A. Trampuz, "Activities of fluconazole, caspofungin, anidulafungin, and amphotericin 
B on planktonic and biofilm candida species determined by microcalorimetry," Antimicrobial Agents and Chemotherapy, vol. 58, no. 5, pp. 2709-2717, 2014.

[70] J. W. Song, J. H. Shin, S. J. Kee et al., "Expression of CgCDR1, CgCDR2, and CgERG11 in Candida glabrata biofilms formed by bloodstream isolates," Medical Mycology, vol. 47, no. 5, pp. 545-548, 2009.

[71] A. Coste, A. Selmecki, A. Forche et al., "Genotypic evolution of azole resistance mechanisms in sequential Candida albicans isolates," Eukaryotic Cell, vol. 6, no. 10, pp. 1889-1904, 2007.

[72] D. Sanglard and F. C. Odds, "Resistance of Candida species to antifungal agents: molecular mechanisms and clinical consequences," The Lancet Infectious Diseases, vol. 2, no. 2, pp. 73-85, 2002.

[73] L. E. Cowen and W. J. Steinbach, "Stress, drugs, and evolution: the role of cellular signaling in fungal drug resistance," Eukaryotic Cell, vol. 7, no. 5, pp. 747-764, 2008.

[74] L. E. Cowen, “The evolution of fungal drug resistance: modulating the trajectory from genotype to phenotype," Nature Reviews Microbiology, vol. 6, no. 3, pp. 187-198, 2008.

[75] R. S. Shapiro, N. Robbins, and L. E. Cowen, "Regulatory circuitry governing fungal development, drug resistance, and disease," Microbiology and Molecular Biology Reviews, vol. 75, no. 2, pp. 213-267, 2011.

[76] N. Cioffi and M. Rai, Nano-Antimicrobials: Progress and Prospects, Springer, 2012.

[77] R. Vazquez-Muñoz, M. Avalos-Borja, and E. Castro-Longoria, "Ultrastructural analysis of Candida albicans when exposed to silver nanoparticles," PLoS ONE, vol. 9, Article ID e108876, 2014.

[78] M. A. Abegg, P. V. G. Alabarse, A. Casanova et al., "Response to oxidative stress in eight pathogenic yeast species of the genus Candida," Mycopathologia, vol. 170, no. 1, pp. 11-20, 2010. 

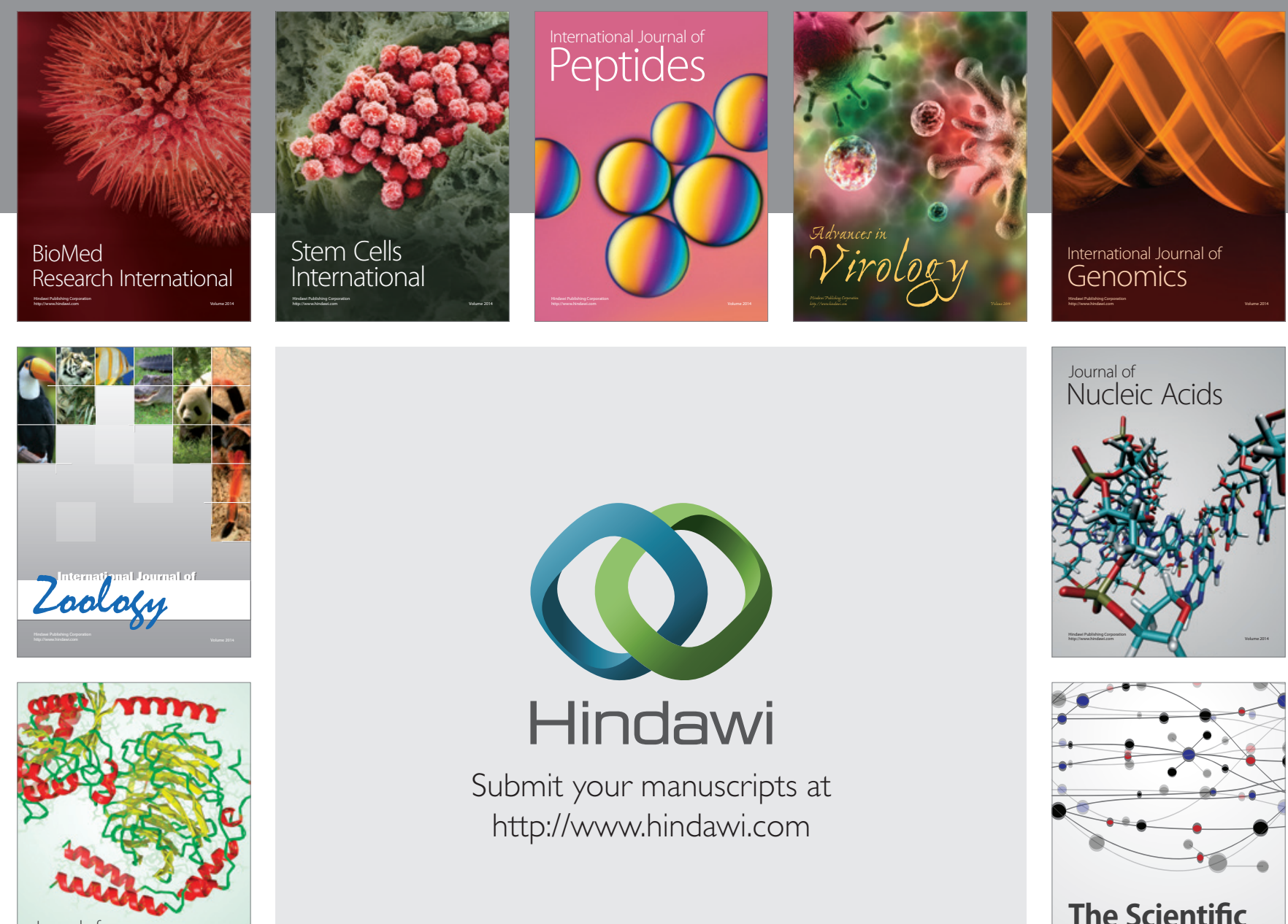

Submit your manuscripts at

http://www.hindawi.com

Journal of
Signal Transduction
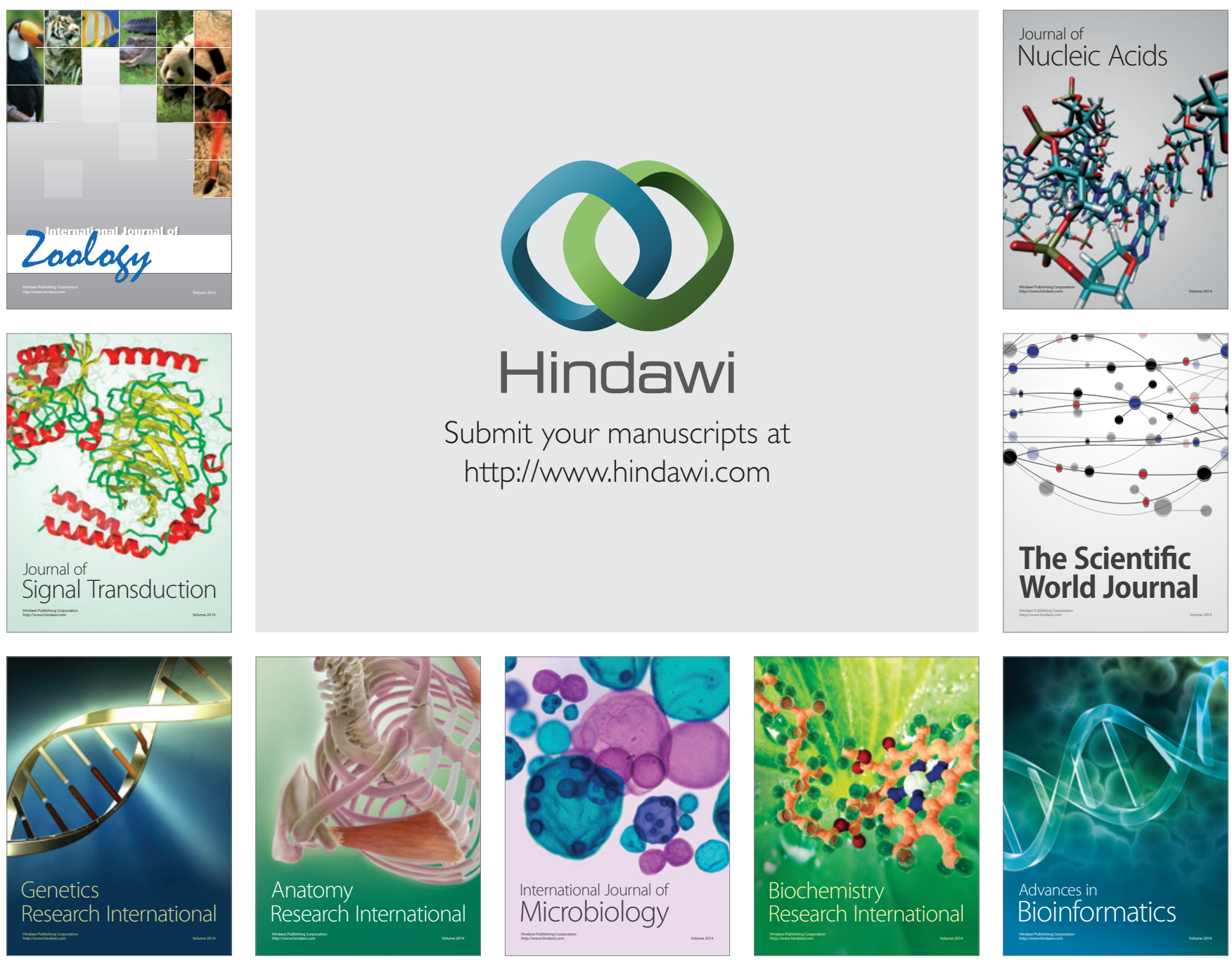

The Scientific World Journal
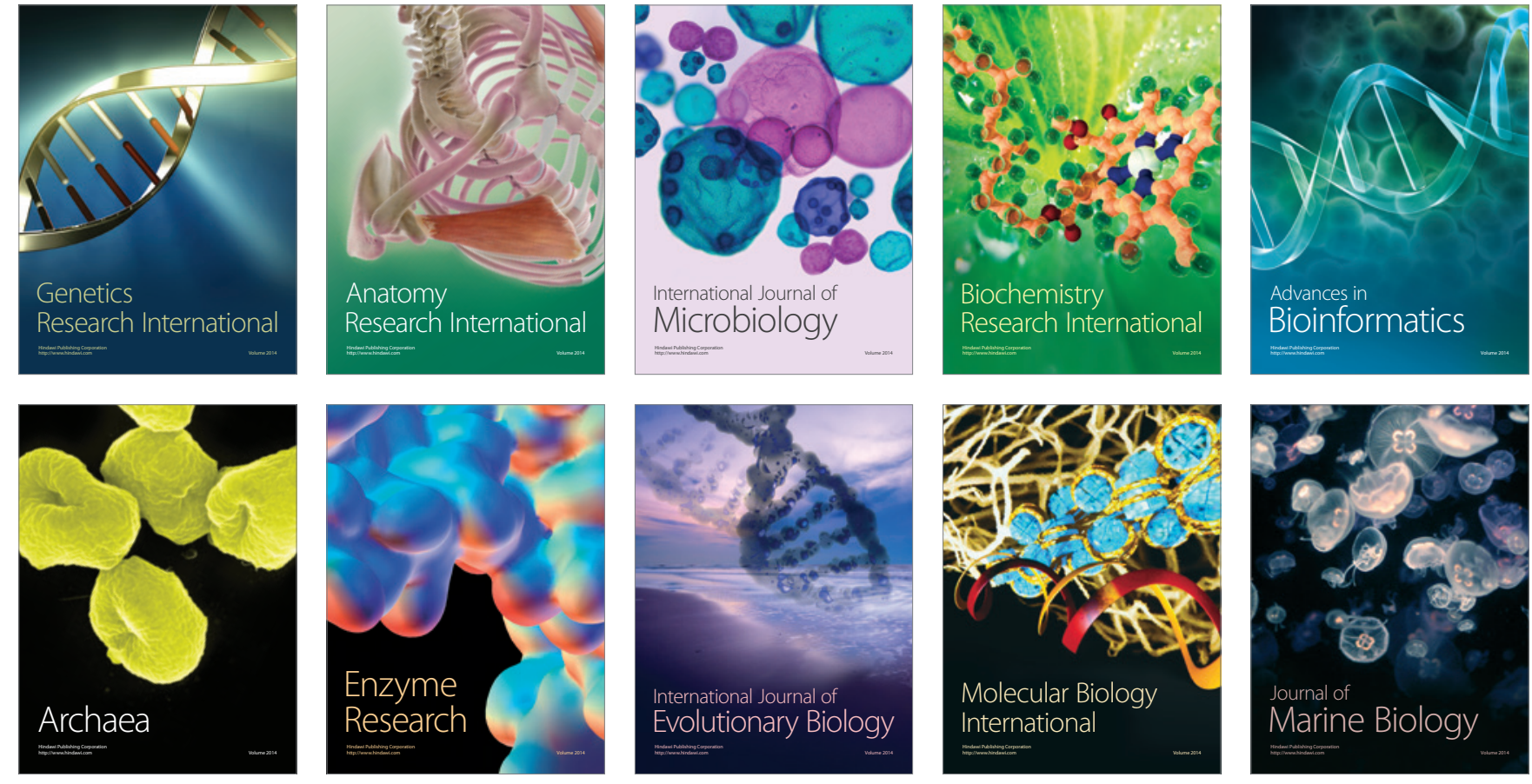